Pontifícia Universidade C Católica

DO RIO DE JANEIRO

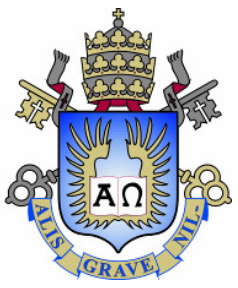

Juliana Giordani Duarte Portella

\title{
A interpretação como processo criativo
}

\section{Monografia}

Monografia apresentada ao Programa de Pós-Graduação em Formação de Intérpretes de Conferências da PUC-Rio como requisito parcial para obtenção do título de Especialista em Interpretação de Conferências.

Orientador: Prof. Christiano Sanches do Valle Silva 


\section{Agradecimentos}

A Deus, criador e sustentador da vida, fonte maior de toda a criatividade.

Ao Junior, meu companheiro, minha inspiração cotidiana.

A meus pais, que me criaram para pensar de modo divergente, estimulando em mim o pensamento crítico desde muito pequena.

À Carol, Vanessa, Andria e Alex, pelo apoio incondicional.

Aos meus amigos, que compreenderam minha ausência no período de pesquisa.

Ao meu orientador Christiano Sanches, por ter acreditado neste trabalho desde o início. Sem o seu direcionamento paciente e seu estímulo a cada passo do caminho, este trabalho não teria sido possível.

A Carlos Roberto Reis de Souza Filho, funcionário da biblioteca, cujo auxílio para obtenção das fontes foi essencial.

Aos professores da PUC-Rio, que me ensinaram a arte de interpretar.

Aos colegas da PUC-Rio, que fizeram a jornada valer a pena. 


\section{Resumo}

Portella, Juliana Giordani Duarte. A Interpretação como processo criativo. Rio de Janeiro, 2014. 59p. Monografia de Conclusão do Curso de Especialização em Formação de Intérpretes de Conferência, CCE, Pontifícia Universidade Católica do Rio de Janeiro.

Esta monografia tem como objeto de estudo a interpretação como processo criativo. O objetivo do trabalho é levantar questões sobre as congruências possíveis entre a criatividade como processo e a atividade da interpretação. Mediante a revisão de literatura das áreas da psicologia, dos Estudos da Tradução e da Interpretação, lançamos aqui as bases de definição da interpretação e da criatividade, enfatizando a interface entre o processo criativo e o processo da interpretação. Dentre os usos e aplicações da criatividade, são destacados o processo criativo e a personalidade criativa. Consideram-se as características da personalidade criativa que são bem-vindas no intérprete, bem como a importância da cultura geral e da preparação para o bom uso da criatividade na tomada de decisões. O trabalho ainda destaca o uso criativo de estratégias de interpretação face à solução de problemas e salienta de que modo a experiência na interpretação pode contribuir para que a criatividade seja melhor utilizada, fornecendo alguns exemplos práticos. Finalmente, o papel da criatividade é salientado mediante os constantes imprevistos que fazem parte do ofício.

\section{Palavras chave:}

Criatividade; estudos da interpretação; processo criativo; personalidade criativa; estratégias de interpretação; solução de problemas; tomada de decisões; pensamento divergente. 


\section{Abstract}

Portella, Juliana Giordani Duarte. Interpreting as a creative process. Rio de Janeiro, 2014. 59p. Monografia de Conclusão do Curso de Especialização em Formação de Intérpretes de Conferência, CCE, Pontifícia Universidade Católica do Rio de Janeiro.

The present paper focuses on interpretation as a creative process. The purpose of the study is to raise issues concerning the possible congruencies between creativity as a process and the interpreting activity. We hereby lay the foundations for the definitions of interpretation and creativity by way of a literature review on the fields of psychology, translation studies, and interpretation studies, emphasizing the interface between the creative process and the interpreting process. Among the different uses and applications of creativity, the creative process and the creative personality are highlighted. The creative personality features that are well-accepted for the interpreter are considered, as well as the importance of general knowledge and preparation for the appropriate use of creativity in decision-making. This paper also draws attention to the creative use of interpreting strategies in problem-solving, and underscores how experience in interpreting may contribute to a better use of creativity, offering a few practical examples. Finally, the role of creativity is stressed before the constant unpredictable situations that are part of this profession.

\section{Keywords:}

Creativity; interpreting studies; creative process; creative personality; interpreting strategies; problem-solving; decision-making; divergent thinking. 


\section{Sumário}

1. Introdução

2. Definição de interpretação 10

2.1. Interpretação Consecutiva 12

2.2. Interpretação Simultânea 12

2.3. Teoria Interpretativa da Tradução: D. Seleskovitch e M. Lederer $\quad 14$

2.4. O Modelo de Esforços: Daniel Gile $\quad 18$

2.5. Comparações entre a Teoria Interpretativa da Tradução e o Modelo de Esforços

3. O que é criatividade? 23

3.1. A criatividade como processo $\quad 24$

3.2. A criatividade na interpretação $\quad 29$

3.3. Características do intérprete criativo 35

3.4. A cultura geral e a preparação no processo criativo $4 \mathbf{4 1}$

3.5. O potencial criativo universal $\quad 43$

4. Estratégias de Interpretação e seu uso criativo 47

4.1. Reformulação 47

4.2. A "Técnica do Salame" 48

4.3. Economia de palavras e omissão 49

4.4. Explicação $\quad 49$

4.5. Entonação, Ênfase e Pausas $\quad 50$

4.6. Números $\quad 50$

4.7. Piadas, metáforas, ditados populares, citações e marcadores de discurso 51

4.8. $O$ uso criativo das estratégias 52

4.9. Estratégias para a interpretação consecutiva 53

4.10. A possibilidade criativa do intérprete experiente 55

4.11. Exemplos criativos na interpretação de conferências 56

4.12. Lidando com o inesperado: uma jornada para toda a vida 58

5. Conclusão 60

6. Referências Bibliográficas 61 
How can one describe the pleasure when on a good day an interpreter feels he is on the crest of a wave, doing a good job and doing something creative, finding expressions in utter freedom with no one to contradict him or suggest alternatives (like a reviser does to a translator!). Just this once, you truly feel on the same wavelength as the speaker, just this once you are rethinking his speech and discreetly touching it up, your spirit is lifting you ever up and up, you are using words you haven't heard for years, specialized words that have risen from the dark depths of your mind, words you didn't know were there, yet now when you need them you hear yourself pronouncing them. Just this once you have full mastery, you are on top of the situation. You are also in the theatre, standing in front of the stage, and the row upon row of listeners are waiting for your every word, pausing with you when you take a breath, following your every intonation. It is heady, it is stimulating, it is intoxicating. Every interpreter has known such moments. One cannot speak of them, of course. There is no common measure between the omnipotence described above, the poetry of the moment, the feeling of eternity, and the banality of the subject being discussed. The subject deserves to be interpreted faithfully of course but it is not of a level to trigger the finer feelings of a human being, aspects of eternity. And yet it does that.

(KERR, 1988 apud TAYLOR-BOULADON, 2007, p. 282) ${ }^{1}$

\footnotetext{
${ }^{1}$ KERR, Anne. Lanterns Over Pinchgut. Sydney: Macmillan, 1988.
} 


\section{Introdução}

A presente monografia trata da perspectiva da interpretação como processo criativo, tanto na modalidade simultânea quanto na consecutiva. Não houve a pretensão de esgotar o tema, dada a sua amplitude, mas ofereço uma entre muitas visões possíveis sobre a criatividade na interpretação.

A motivação deste trabalho se deve a algumas percepções na prática em sala de aula ao longo do Curso de Formação de Intérpretes de Conferência da PUCRio. Percebi que, a fim de fazer um bom trabalho, é importante que o intérprete demonstre características como fluidez, flexibilidade, fluência, elaboração, percepção aguçada das informações extralinguísticas presentes no evento e originalidade na solução das mais diversas dificuldades que se apresentam. É necessário levar em consideração o tom da conferência, o nível de formalidade do evento, quem são os oradores, quem é o público, a linguagem corporal e expressão facial dos palestrantes, dentre muitos outros componentes que fomentam a criatividade na tomada de decisões.

Ter de dialogar com tantos elementos ao mesmo tempo em que se faz uma tradução oral, em tempo real, sem ter mais do que alguns segundos para reagir à mensagem, me levou ao questionamento sobre quais outros fatores poderiam estar envolvidos no processo de interpretação, além da tradução das palavras. Quanto mais avançava no curso, mais percebia que não se tratava de uma atividade mecânica, mas sim de um processo que exigia alto nível de energia mental e adaptabilidade. A beleza da interpretação não estava em pensar somente nas palavras que estavam sendo proferidas pelo orador, mas no sentido do que ele estava querendo dizer, e na melhor maneira de transmitir aquela mensagem para outra língua e cultura. Percebi que o conteúdo da mensagem poderia ser o mesmo, mas tratava-se, possivelmente, de um novo produto, para o qual se exige um processo criativo. Percebi, ainda, que as melhores interpretações que tive a oportunidade de ouvir traziam consigo soluções incrivelmente ágeis e adequadas.

Meu interesse na interface entre a criatividade e a interpretação também se deve a diversas atividades que desenvolvi previamente no campo das artes cênicas, bem como a um apreço pessoal pela arte e pela estética. Intrigava-me a descoberta do papel que a criatividade poderia ter na interpretação. 
A rigor, há muitas outras definições, usos e aplicações da criatividade, sendo este apenas um recorte do assunto. A metodologia de pesquisa empregada foi pautada na análise e reflexão, tendo como base a literatura existente de teóricos renomados. Na busca por material, recorri a um bom embasamento tanto nos Estudos da Tradução e Interpretação quanto no campo da criatividade, à luz da psicologia. Para tanto, fez-se necessária uma investigação das definições usuais do que vem a ser a criatividade em si, para que esse conceito fosse então aplicado à atividade da interpretação, que também foi delineada. $\mathrm{O}$ presente estudo avalia não só a interpretação como processo criativo e as diferentes maneiras em que a criatividade pode ser empregada na atividade da interpretação, mas salienta também situações em que se faz necessário o uso criativo de estratégias possíveis para uma interpretação mais completa.

Acredito que este trabalho encontra o seu valor, tanto para intérpretes quanto para não intérpretes, ao ampliar sua visão quanto às próprias definições de criatividade e o seu papel no processo da interpretação. Os não intérpretes interessados nas artes talvez se surpreendam com o quanto a atividade da interpretação exige em criatividade, e os intérpretes céticos quanto ao tema podem vir igualmente a se encantar com as evidências. A pesquisa lança luz sobre diversos aspectos do ofício, fornecendo um olhar diferente dessa profissão tão mal compreendida, muitas vezes encarada por leigos como atividade mecânica de mera tradução de palavras.

O primeiro capítulo traz a definição de interpretação de conferência, tanto simultânea quanto consecutiva. Recorro a Danica Seleskovitch (1975, 1978), Marianne Lederer (1978) e Daniel Gile (2002, 2009) para uma melhor compreensão do que é a interpretação em seus processos. Comparo as contribuições do Modelo de Esforços e da Teoria Interpretativa da Tradução, salientando sua complementaridade no que tange aos processos mentais: a desverbalização do sentido, os complementos cognitivos extralinguísticos, os esforços de processamento cognitivo envolvidos, a reformulação e a reexpressão da mensagem na língua de chegada.

Em seguida, forneço algumas definições de criatividade, com foco na criatividade como processo e sua confluência com o processo da interpretação, tendo como base teórica a psicologia e os Estudos da Tradução e Interpretação. Destaco algumas características da personalidade criativa, salientando os motivos 
pelos quais tais qualidades são bem-vindas no intérprete. Ressalto a importância da cultura geral e da preparação para o processo criativo da interpretação, sendo elementos-chave para sua realização. Abordo ainda o potencial criativo universal, esclarecendo que todos podem desenvolver e estimular a criatividade.

Em último lugar, listo algumas das estratégias comumente utilizadas na prática de interpretação, ressaltando seu uso criativo na interpretação simultânea e consecutiva. Falo também do potencial criativo do intérprete profissional mais experiente, explicando de que modo sua avançada prática na profissão permite maior espaço para a criatividade. A apresentação de exemplos práticos, ao final do trabalho, visa ajudar o leitor a compreender melhor a relevância da criatividade no cotidiano do intérprete, tanto no que tange soluções linguísticas quanto no que diz respeito a soluções que demandam comportamento e personalidade criativa por parte do intérprete.

Lancemos as bases do trabalho, portanto, começando pela definição de interpretação. 


\section{Definição de Interpretação}

A fim de salientarmos o papel da criatividade no ofício da interpretação, faz-se necessária uma boa definição de interpretação. Trata-se de uma profissão ainda pouco conhecida, e muitos que a conhecem talvez não saibam que propriedades a definem. O que é interpretação? De que maneira ela é praticada? O que ocorre no processo da interpretação? Quais são os modelos teóricos existentes para que a compreendamos?

Franz Pöchhacker (2004) nos ajuda a estruturar uma definição adequada de interpretação. Remontando a teorias da tradução e apresentando diferentes abordagens da interpretação como tradução oral, ele chega a algumas conclusões: trata-se de uma atividade ou serviço que envolve a produção de discursos (orais ou por língua de sinais) numa determinada situação e cultura. Esses discursos produzidos têm sentido e/ou efeito semelhante a discursos prévios, produzidos em outra língua e cultura. Pöchhacker também salienta a observação feita por Otto Kade (1968 apud PÖCHHACKER, 2004) ${ }^{2}$, de que na interpretação o discurso original é apresentado uma única vez (não pode ser revisado ou repetido) e a interpretação do discurso (ou o discurso interpretado) é produzida sob a pressão da restrição de tempo, com poucas oportunidades de correção e revisão, sendo, assim, uma atividade imediata, produzida em tempo real (PÖCHHACKER, 2004).

Para os propósitos práticos do trabalho em questão, elaborei uma definição que não se pretende final, mas que salienta os principais aspectos da atividade de interpretação, com base nos elementos apontados por Pöchhacker e Kade: $A$ interpretação é um tipo de tradução produzida em tempo real, sob a pressão de tempo restrito. É uma atividade que consiste na produção de discursos orais ou em sinais, em uma determinada situação e cultura, que têm sentido elou efeito semelhante a discursos prévios, proferidos em outra língua e cultura, uma única vez.

O contexto cultural da interpretação é tão importante quanto os idiomas utilizados. Roderick Jones (2002) salienta a importância da sensibilidade do

\footnotetext{
2 Kade, Otto. Zufall und Gesetzma $\square$ Bigkeit in der $\mathbf{U} \square$ bersetzung. Leipzig: Verlag Enzyklopädie, 1968.
} 
intérprete como alguém que reduz a distância cultural entre os participantes de um determinado evento:

A dificuldade de comunicação é, portanto, muito mais do que a mera dificuldade de tradução. (...) A tarefa do intérprete é dar sentido ao texto para o público-alvo, se necessário (e se possível) fornecendo as devidas explicações ou até mesmo modificando as referências originais do orador, contanto que transmita ao público exatamente o que o orador quis dizer. (...) O intérprete deve fazer com que seu público entenda o verdadeiro sentido, quer seja pela escolha criteriosa de sinônimos, quer por paráfrase, ou pelo menos pelo tom de voz adequado. (...) Em todos estes casos e, certamente, em todo o seu trabalho, o intérprete deve ser a ponte entre as barreiras culturais e conceituais que separam os participantes em uma reunião. (...) Sua tarefa é certificar-se de que a mensagem está sendo de fato assimilada pelo público. (JONES, 2002, p. 3-4) ${ }^{34}$

Por esse motivo, podemos desconsiderar a noção equivocada de que, para ser um bom intérprete, basta dominar os idiomas de trabalho. Jean Herbert, pertencente à primeira geração de intérpretes da Organização das Nações Unidas e um dos pioneiros em interpretação consecutiva para a Liga das Nações, citado por Valerie Taylor-Bouladon (2001), afirma:

É indispensável ser bilíngue para ser intérprete, assim como deve-se primeiro ter um violino para tocá-lo. Ter um violino não faz de alguém violinista. Da mesma forma, o conhecimento linguístico não é nada mais do que um instrumento nas mãos de alguém que deseja tornar-se intérprete. (KERR, 1998 apud TAYLORBOULADON, 2001, p. 52)

Uma vez dominando as línguas de trabalho, a pessoa que deseja tornar-se intérprete passa por treinamento adequado na área de interpretação, a fim de aprender e praticar técnicas e estratégias específicas para o ofício. Não faz parte do escopo deste trabalho entrar em detalhes sobre a formação de intérpretes; contudo, mais informações podem ser encontradas nos sites das instituições que

\footnotetext{
${ }^{3}$ Esta e todas as demais citações em língua estrangeira foram traduzidas pela autora deste trabalho.

${ }^{4}$ Communication difficulties are thus much more than pure translation difficulties. (...) The interpreter's task is to instill meaning into the text for the target audience, if necessary (and if possible) providing the requisite explanations or even changing the original speaker's references, provided this conveys to the audience precisely what the speaker wanted to say. (...) The interpreter must make their audience understand the real meaning, either through judicious choice of synonyms or by rewording a sentence, or at least through the appropriate tone of voice. (...) In all of these cases, indeed in all of their work, interpreters must bridge the cultural and conceptual gaps separating the participants in a meeting. (...) their task is to make sure that the message is genuinely assimilated by the audience.

${ }^{5}$ While for interpreting it is indispensable to be bilingual, just as in order to play the violin one must first have a violin, the fact of having a violin does not make one a violinist, and similarly knowledge of languages is no more than an instrument in the hands of someone wishing to become an interpreter.
} 
oferecem cursos de pós-graduação para a formação em interpretação de conferências.

A interpretação é uma atividade realizada em diversos contextos e condições diferentes, principalmente em duas modalidades que abordarei a seguir: interpretação consecutiva e interpretação simultânea.

\subsection{Interpretação Consecutiva}

A interpretação consecutiva ocorre quando o intérprete primeiro ouve o orador, para depois reproduzir o discurso na língua de chegada, tendo como base sua memória e anotações. Assim, o intérprete profere o discurso interpretado consecutivamente, ou seja, logo após o discurso original (JONES, 2002). Na interpretação consecutiva, geralmente o orador profere o discurso por alguns minutos, para depois dar vez à interpretação. Há oradores que preferem enunciar somente algumas frases por vez, caso em que é possível para o intérprete confiar somente em sua memória, sem necessidade de tomar muitas notas. É o que se chama de interpretação intermitente, na qual os turnos entre orador e intérprete são mais curtos do que na consecutiva em si. A fim de lidar com a modalidade consecutiva, o intérprete aprende, em seu treinamento, técnicas de anotação (símbolos, abreviações, organização das notas na página, dentre outras), para que possa lidar com durações variadas de discurso - técnicas essas que destacarei mais à frente.

$\mathrm{Na}$ interpretação consecutiva, utiliza-se um bloco de anotações e, se necessário, um microfone. $\mathrm{O}$ intérprete se posiciona próximo ao orador e profere o discurso na língua de chegada diante dos presentes. O intérprete deve ser rápido e eficiente, levando um pouco menos de tempo que o orador ao proferir o discurso na língua de chegada. Como regra geral, o ideal é que se leve três quartos do tempo da elocução do discurso original (JONES, 2002).

\subsection{Interpretação Simultânea}

$\mathrm{Na}$ interpretação simultânea, o intérprete inicia a interpretação do discurso logo após o início da fala do orador, mantendo-a enquanto o discurso original continua a ser proferido, para terminar a interpretação quase ao mesmo tempo 
que o orador. Portanto, o intérprete profere a interpretação simultaneamente ao discurso original (JONES, 2002).

Para que essa modalidade de interpretação seja possível, faz-se necessário o uso de equipamentos adequados, como transmissor, receptores, fones de ouvido e cabine à prova de som. Quando o intérprete traduz para somente um ou dois participantes, é possível fazer a tradução simultânea sussurrada, para a qual não há a necessidade de quaisquer equipamentos. Nesse caso, o intérprete se posiciona próximo aos dois participantes do evento para quem vai interpretar, e faz a tradução simultânea do discurso com voz suave porém audível, com tom de voz mais baixo do que o tom de voz do orador, para não atrapalhar o andamento da reunião (PÖCHHACKER, 2004).

Nas duas modalidades de interpretação, o intérprete precisa primeiro ouvir a mensagem na língua de partida, compreender e processar a informação, para depois verter o sentido da mensagem na estrutura linguística mais adequada na língua de chegada. A principal diferença entre as duas modalidades é que, no caso da interpretação consecutiva, o intérprete primeiro ouve uma ideia completa da mensagem para logo depois fazer a tradução, ao passo que, na interpretação simultânea, o intérprete vai processando e traduzindo a informação enquanto a ideia ainda está sendo pronunciada pelo orador. Nos dois casos, todavia, o intérprete trabalha em tempo real, ou seja, não pode demorar mais do que o orador para transmitir a mensagem na língua de chegada e precisa reagir imediatamente à mensagem proferida, rápida e eficientemente (JONES, 2002).

Trabalhar em tempo real e restrito, sob estresse, numa atividade que exige concentração intensa, sobrecarrega a capacidade cognitiva do intérprete de tal maneira que a qualidade de sua interpretação é mantida por curtos períodos. Por esse motivo, o trabalho é compartilhado por dois intérpretes, que geralmente se revezam a cada trinta minutos.

A fim de lidar com as restrições na atividade da interpretação, surgiram teóricos que se preocuparam em lançar as bases para reduzir as dificuldades comumente encontradas por intérpretes em seu ofício, na tentativa também de esclarecer o que ocorre durante o processo de interpretação. Destacamos aqui os trabalhos de Danica Seleskovitch, Marianne Lederer e Daniel Gile, que veremos a seguir. 


\subsection{Teoria Interpretativa da Tradução ${ }^{6}$ : Seleskovitch e Lederer}

A Teoria Interpretativa da Tradução, conforme postulada por Danica Seleskovitch e posteriormente desenvolvida por Marianne Lederer, tem como ponto de partida a observação da interpretação consecutiva (contudo, também explica o que ocorre no processo da tradução simultânea). Para Seleskovitch e Lederer (1989) ${ }^{7}$, a interpretação compreende 3 etapas:

1) a fusão dos elementos do sentido linguístico com o conhecimento extralinguístico para obter o sentido; 2) a desverbalização desse sentido à medida que ele surge; e 3) a expressão espontânea desse sentido de modo linguístico.

(SELESKOVITCH \& LEDERER, 1989, p. 21 apud FREIRE, 2008, p. 153)

Seleskovitch (1978) defendia que o intérprete deve sempre interpretar o sentido do que foi dito, ao invés de traduzir palavras. O sentido está contido nas ideias por trás das palavras, e só pode ser compreendido e interpretado enquanto o idioma é utilizado no processo discursivo. O intérprete não deve, portanto, se ater à semântica, à fonética ou ao significado linguístico isolado das palavras durante a interpretação, mas sim ao sentido do que foi dito, ao que o orador quis dizer.

As palavras utilizadas na língua de partida só são relevantes no contexto utilizado. É o contexto que vai auxiliar na compreensão, por parte do intérprete, do sentido do discurso proferido pelo orador, auxiliado pela cultura geral e preparação para o evento. Nesse momento de compreensão do sentido, há uma complementaridade cognitiva, isto é, uma fusão das ideias por trás das palavras do discurso com o conhecimento extralinguístico do intérprete (contexto, preparação, cultural geral):

O conhecimento prévio é uma expressão vazia que abrange diversos "complementos cognitivos" que nos ajudam a entender o discurso. Esses complementos cognitivos incluem o conhecimento de mundo, do momento, do lugar, das circunstâncias nas quais um discurso é formulado, da memória do que foi dito anteriormente, do conhecimento de quem é o locutor e de quem são os ouvintes. (LEDERER, 1990, p. 53, apud FREIRE, 2008, p. 155) ${ }^{8}$

\footnotetext{
${ }^{6}$ Também conhecida como Teoria do Sentido (no original, "Théorie du Sens"). Nota da autora.

${ }^{7}$ LEDERER, M \& SELESKOVITCH, D. The Interpretation Process. In: A Systematic Approach to Teaching Interpretation. Paris: European Communities, 1989. p. 21-26.

${ }^{8}$ LEDERER, Marianne. The Role of Cognitive Complements in Interpreting. In: BOWEN, David \& BOWEN, Margareta (orgs.). Interpreting - Yesterday, Today, and Tomorrow. ATA Monograph Series, v. IV. Binghamton: State University of New York, 1990, p. 53-60.
} 
Seleskovitch (1978) compara a compreensão do sentido pelo intérprete com a compreensão normal de ouvintes em sua língua materna. Como falantes, temos por intenção direcionar os ouvintes para as nossas ideias, sentimentos, opiniões, e não nossas palavras. Comparativamente, como ouvintes,

temos consciência do que compreendemos, mas não das palavras que desencadearam aquela compreensão. À exceção da poesia, não nos lembramos das palavras que ouvimos ao escutarmos a explanação das ideias de alguém. (p. 336) ${ }^{9}$

Lederer (1978) afirma que o sentido é a combinação da compreensão linguística imediata com o conhecimento prévio, de modo que a compreensão do sentido se dá por meio do acréscimo de um elemento cognitivo. Essa construção cognitiva se dá, portanto, na combinação dos sons proferidos na língua de partida — sons que "ativam" a compreensão do sentido — associados a lembranças cognitivas, a conhecimentos adicionais e à memória de curto prazo do que já foi dito (FREIRE, 2008, p. 7). Seleskovitch (1978) defende, entre outros aspectos, que o sentido é não-verbal porque assim que é compreendido, é imediatamente dissociado de qualquer forma linguística na memória cognitiva.

A fim de interpretar e preservar o sentido do discurso, portanto, o intérprete deve se valer do recurso da desverbalização, dissociando as ideias das palavras (FREIRE, 2008). O intérprete faz uso da sua "memória não-verbal" para reacessar o conteúdo do discurso enquanto interpreta. Segundo Glória Regina Loreto Sampaio,

A desverbalização consiste em: 1) captar o sentido expresso pelo palestrante em um idioma estrangeiro; 2) "despir" esse sentido das palavras com que estava "vestido", recorrendo constantemente aos complementos cognitivos disponíveis; e 3) "vestir" o sentido expresso no idioma estrangeiro com nova "roupagem" - i. e., as palavras no idioma materno (SAMPAIO, 2007, comunicação em sala de aula, apud FREIRE, 2008, p. 156).

A desverbalização é de extrema importância para a comunicação fiel do sentido do discurso, pois a mera transcodificação das palavras (ou seja, seu significado linguístico literal), não daria conta de expressar o que de fato foi dito. A tradução literal das palavras não faria sentido na língua de chegada; seria o que

\footnotetext{
9 "we are conscious of what we understand but not of the words that triggered off that understanding. With the exception of poetics we do not keep in mind the words we hear when listening to somebody explaining his ideas."
} 
chamamos de "linguística contrastiva", uma "tradução automática" - coisa que as máquinas são capazes de fazer, conforme afirma Lederer (1990):

As diferenças em termos de estrutura linguística são velhas conhecidas, porém, limitar a pesquisa à gramática e à linguística contrastiva não levou a ciência da tradução além do ponto que a tradução automática pôde atingir (LEDERER, 1990, p. 59, apud FREIRE, 2008, p. 156)

A transcodificação é "a tradução sem desverbalização, em que se traduzem as palavras de uma língua por equivalências convencionalmente pré-estabelecidas em outra língua" (PAGURA, 2012, p. 97). A transcodificação pode e deve ser utilizada de modo pontual: para termos técnicos, números, nomes próprios, siglas, ou em breves momentos em que a intenção do orador não é claramente compreendida (PAGURA, 2012).

A desverbalização, portanto, é crucial no processo de interpretação porque

os diferentes idiomas não se utilizam do mesmo grupo de palavras para se referirem aos mesmos objetos ou conceitos, de modo que os indivíduos, em seus idiomas próprios, não se valem das mesmas palavras para expressar as mesmas ideias. Se a interpretação fosse realizada tendo como base as palavras e não o sentido, os ouvintes teriam dificuldade de compreender as ideias contidas em conjuntos de palavras que eles mesmos não utilizariam daquela forma. $\left(\right.$ SELESKOVITCH, 1978 , p. 337) ${ }^{10}$

Por isso, o intérprete deve, acima de tudo, ser capaz de compreender ideias e seguir a linha de raciocínio do orador, sempre buscando entender sua intenção ("vouloir-dire"), de modo que a habilidade linguística é somente um pré-requisito. Essa foi inclusive a base do pensamento idealizador da famosa ESIT (Escola Superior de Intérpretes e Tradutores) de Sorbonne (SELESKOVITCH, 1978).

Numa conferência, o que foi dito é mais importante do que como foi dito. $\mathrm{Na}$ interpretação consecutiva o processo de desverbalização é mais aparente, pois o intérprete só pode traduzir "o que foi dito" após ter compreendido as ideias contidas naquele trecho do discurso, tomando nota, quando possível, das "unidades de sentido" e dos elementos de ligação entre essas unidades.

\footnotetext{
10 ...languages do not use the same set of words to point to the same objects or concepts so that speakers in individual languages do not use the same words to express the same ideas. Should interpreting be carried out on the basis of language and not of sense, listeners would have difficulties in discovering the ideas behind assemblies of words they themselves would never use in that way.
} 
As "unidades de sentido", de acordo com Marianne Lederer (1978), são fragmentos de sentido que surgem, de modo irregular, na mente dos ouvintes desejosos de compreender uma determinada mensagem proferida. Do mesmo modo, a compreensão do intérprete se dá nessas "unidades de sentido", que são armazenadas em sua memória de curto prazo continuamente - ou ao mesmo tempo em que interpreta, na modalidade simultânea, ou de modo consecutivo, primeiro tomando notas ou somente ouvindo, para depois interpretar. De qualquer forma, o intérprete precisa reconhecer essas unidades de sentido, a fim de se alinhar com a intenção do orador no desenrolar de sua cadeia discursiva.

No processo da interpretação, as unidades de sentido surgem da associação das palavras proferidas com a memória cognitiva (experiências, cultura geral, preparação) do ouvinte, que, nesse caso, é o intérprete:

As unidades de sentido são a síntese de uma série de palavras presentes na memória de curto prazo, associadas a experiências cognitivas anteriores ou recordações. Esta fusão de sentido deixa registros cognitivos na memória, enquanto a memória de curto prazo continua a absorver e armazenar as palavras que se seguem, até que ocorra uma nova síntese e uma nova unidade de sentido seja acrescentada àquelas previamente armazenadas na memória cognitiva. (LEDERER, 1978, p. 138) ${ }^{11}$

A interpretação, portanto, é um processo sintético, não analítico. Ao continuamente compreender as unidades de sentido no desenrolar da cadeia discursiva do orador, desverbalizando-as e mantendo-as em sua memória de curto prazo, o intérprete pode então reexpressar, na língua de chegada, essa mesma cadeia discursiva, da maneira mais adequada possível no contexto em que se encontra:

O processo da tradução consiste em resgatar da formulação na língua de partida o sentido que ela designa, sentido este que a formulação não mais contém após sua expressão na língua de chegada. Entre o original e sua tradução encontra-se a ideia desverbalizada que, uma vez apreendida conscientemente, pode ser expressa em quaisquer idiomas. Quando se depara com um enunciado, o intérprete não se pergunta “o que significa, geralmente, cada uma dessas palavras?", mas sim "o que

\footnotetext{
${ }^{11}$ Units of meaning are the synthesis of a number of words present in short-term memory associating with previous cognitive experiences or recollections; this merging into sense leaves a cognitive trace in the memory while the short-term memory is taking up and storing the ensuing words until a new synthesis occurs and a new cognitive unit adds up to those previously stored in the cognitive memory.
} 
significam estas palavras, esta frase, aqui e agora?" (SELESKOVITCH, 1984, p. 104-105, apud FREIRE, 2008, p. 158, destaques de FREIRE) ${ }^{12}$

$\mathrm{Na}$ reexpressão da mensagem em outro idioma, o intérprete recorre à significação pertinente e equivalente ao sentido daquilo que foi proferido.

Esse processo sintético que é a interpretação - que passa pela fusão dos elementos linguísticos e extralingüísticos para obtenção do sentido, pela desverbalização e pela reexpressão do sentido, envolvendo a compreensão das unidades de sentido enquanto a cadeia discursiva do orador se desenrola demanda enorme esforço cognitivo. Vejamos a seguir de que modo Daniel Gile (2002, 2009) contribuiu para esclarecer os esforços de processamento cognitivo na interpretação, através de seu Modelo de Esforços.

\subsection{O Modelo de Esforços: Daniel Gile}

Daniel Gile, autor influente desde meados da década de 1980 (período tido como a "Renascença" da pesquisa na área de interpretação de conferências), tem sido amplamente conhecido por seu compromisso com a pesquisa e a cooperação internacional nos Estudos da Interpretação. Seu "Modelo de Esforços" foi provavelmente sua principal contribuição teórica nessa área de pesquisa, ao salientar os esforços de processamento cognitivo na interpretação. Desde seu desenvolvimento inicial, o Modelo de Esforços tem sido cada vez mais elaborado e aplicado à prática da interpretação (PÖCHHACKER \& SHLESINGER, 2002). O modelo de Gile, portanto, merece destaque, já que lança um olhar singular no processo de interpretação como um processo de esforços cognitivos.

Dentre outros motivos, o Modelo de Esforços surgiu a partir do momento em que Gile observou que havia numerosos erros, omissões, limitações e falhas de desempenho, mesmo na interpretação realizada por intérpretes experientes e até especialistas em áreas da interpretação que exigem vocabulário mais técnico, como no caso de medicina e direito, por exemplo. Números e nomes incorretos foram identificados no desempenho de diversos intérpretes, com maior ou menor experiência, mesmo em condições favoráveis de trabalho - sem que houvesse

${ }^{12}$ SELESKOVITCH, Danica. Interpreter un Discours n'est pas Traduire une Langue. In: LEDERER, M. \& SELESKOVITCH, D. Interpreter pour Traduire. Paris: Publications de la Sorbonne, 1984, p. 104-115. 
problemas com o som, velocidade na fala ou pronúncia do orador de difícil compreensão, discurso técnico ou complexo. Gile se propôs, assim, a investigar o que poderia precipitar falhas tão numerosas em situações favoráveis de trabalho, dando origem ao Modelo de Esforços, citado pela primeira vez em 1983. Seu modelo pretende explicar os motivos que precipitam erros comumente encontrados na interpretação simultânea, modalidade utilizada como ponto de partida de suas pesquisas (GILE, 1997).

Gile defende que o processo de interpretação compreende três esforços cognitivos principais: 1) esforço de audição e análise (L); 2) esforço de produção (P); e 3) esforço de memória de curto prazo (M). Além desses três esforços, há também o esforço de coordenação (C), que tem um papel de moderação dos outros três esforços (GILE, 2009). O autor explica (1997) que o esforço de audição e análise (L) envolve operações de compreensão, incluindo a decisão final do intérprete quanto ao sentido do que foi ouvido; o esforço de produção (P) vai desde o momento da representação mental inicial da mensagem, passa pelo planejamento de como esse sentido será expresso na língua de chegada, até a execução desse mesmo planejamento; e o esforço da memória de curto prazo (M) lida com a limitação do tempo, exigindo várias estratégias e táticas de armazenamento (até que o contexto fique mais claro) ou liberação rápida da informação na língua de chegada, para não sobrecarregar esse esforço. A todos esses esforços se soma o esforço da coordenação dos esforços (C), que faz uma espécie de "malabarismo" para que o equilíbrio da qualidade da interpretação seja mantido, já que todos os esforços são constantemente utilizados, muitas vezes concomitantemente, como no caso da modalidade simultânea de interpretação.

O Modelo de Esforços de Daniel Gile parte de dois pressupostos principais: 1) são necessários esforços cognitivos por parte do intérprete para desempenhar sua função nos eventos de interpretação, sendo que o intérprete tem uma capacidade limitada de realização de tais esforços; 2) os eventos apresentarão demandas de esforço cognitivo que muitas vezes ultrapassarão a capacidade disponível de processamento que o intérprete possui (FREIRE, 2008). Em outras palavras, cada evento exige do intérprete uma Capacidade Total de Processamento (CTP), que inclui as demandas específicas de cada um dos esforços despendidos pelo intérprete. O intérprete, por sua vez, apresenta sua Capacidade Disponível de Processamento (CDP), que inclui sua capacidade disponível para cada um dos 
esforços utilizados em sua prática (FREIRE, 2008). O desempenho do intérprete é insatisfatório, portanto, quando há uma sobrecarga cognitiva dos esforços despendidos (CTP>CDP ou demanda maior que a disponibilidade de algum dos esforços), levando o intérprete a erros e/ou omissões. O esgotamento dos esforços em relação à demanda sempre ocorrerá, já que a Capacidade Disponível de Processamento é finita (GILE, 1997).

Gile faz um apanhado de estudos realizados por autores da Psicologia Cognitiva, chegando à conclusão de que os esforços despendidos na atividade da interpretação estão na categoria das operações mentais não automáticas. O ofício do intérprete exige constante atenção diante da demanda de processamento cognitivo necessária para desempenhar sua função, além de também levá-lo a lidar com estímulos desconhecidos e condições desfavoráveis de trabalho (FREIRE, 2008).

O Modelo de Esforços também identifica problemas que podem precipitar erros ou omissões por parte do intérprete devido a um aumento na demanda de sua capacidade de processamento: números, listas, siglas, alta velocidade na fala do orador, discursos lidos (não espontâneos), sotaques de difícil compreensão, discursos altamente densos, acúmulo de termos técnicos, diferenças entre estruturas sintáticas dos idiomas, fatores externos (qualidade do som, ambiente barulhento), dentre vários outros (GILE, 1997). Nesses exemplos, podemos identificar que há uma saturação do canal de comunicação com relação à demanda - ou porque a Capacidade Disponível de Processamento (CDP) do intérprete é insuficiente para atender à demanda, ou porque houve uma saturação de um dos esforços diante de uma demanda alta demais (FREIRE, 2008).

O Modelo de Esforços de Daniel Gile nos fornece uma explicação interessante do processo de interpretação, pois salienta o fluxo constante de energia mental necessária, de acordo com a demanda. A condição ideal de um evento, portanto, ocorre quando a Demanda operacional Total (DT) do evento é menor do que a Capacidade de processamento disponível Total (CT) do intérprete. Gile $(1995)^{13}$ explica, metaforicamente, tal condição ideal:

A interpretação é semelhante a uma festa para a qual foram convidados A, P e M. Para que eles fiquem satisfeitos, duas condições devem ser atendidas: além de a

${ }^{13}$ GILE, Daniel. The Effort Models in Interpretation. In: Basic Concepts and Models for Interpreter and Translator Training. Amsterdam/Philadelphia: John Benjamins, 1995. p. 157190. 
quantidade total de vinho (V) ser suficiente para saciar a sede dos convidados, o anfitrião deve ser capaz de encher o copo de cada um deles assim que ficar vazio (Gile, 1995, p. 171-172 apud FREIRE, 2008, p. 164).

Através de seu Modelo de Esforços, Gile esclarece que o intérprete precisa lidar constantemente com a defasagem que geralmente há entre sua energia mental disponível e a energia mental exigida para operacionalizar todos os esforços necessários à tarefa em questão.

Vejamos agora quais os pontos de encontro entre o Modelo de Esforços de Gile e a Teoria Interpretativa da Tradução, de Seleskovitch e Lederer.

\subsection{Comparações entre a Teoria Interpretativa da Tradução e o Modelo de Esforços}

A Teoria Interpretativa da Tradução de Danica Seleskovitch e o Modelo de Esforços de Daniel Gile, apesar de terem como objeto primeiro de observação modalidades distintas da interpretação - consecutiva e simultânea, respectivamente - partilham conceitos e podem ser encaradas como visões complementares. As duas visões foram amplamente utilizadas e aplicadas, enriquecendo as pesquisas e fomentando a discussão no campo dos Estudos da Interpretação.

Seleskovitch e Lederer se concentraram na importância da desverbalização na interpretação, enquanto Daniel Gile evidenciou o quanto a atividade da interpretação muitas vezes sobrecarrega a capacidade cognitiva do intérprete. Os dois modelos concordam quanto à importância da apreensão do sentido do discurso, reconhecendo que a transcodificação ("tradução literal”) é um empecilho à interpretação - ou porque o intérprete não conseguiria acompanhar a linha de raciocínio do orador, se perdendo nas palavras, ou porque sua capacidade de processamento pode se esgotar na tradução, palavra por palavra (FREIRE, 2008). Apesar dos modelos citados enfatizarem, inicialmente, modalidades distintas da interpretação, as duas visões entendem que o armazenamento do discurso na memória de curto prazo deve levar em consideração o contexto. Essa "memória contextualizada", somada a outros complementos cognitivos (cultural geral, preparação, informações extralinguísticas) e a esforços de análise, permitirão ao intérprete construir em sua mente o sentido do que foi dito para que possa reexpressá-lo na língua de chegada. 
As duas visões se valem de metáforas para explicar como o processo de interpretação funciona: Seleskovitch e Lederer sugerem a "troca de vestimentas" como metáfora para apreender o sentido e dar a ele uma nova "roupagem", já Gile se vale do "abastecimento constante dos copos" para exemplificar o dispêndio constante de energia mental que a atividade da interpretação demanda (FREIRE, 2008).

Tanto Seleskovitch quanto Gile fizeram contribuições valiosas para o campo da interpretação, fornecendo perspectivas diferentes sobre o ofício. Os dois modelos consideram os imprevistos e a necessidade de lidar com eventuais condições desfavoráveis de trabalho, oferecendo orientações sobre como lidar com as dificuldades. O uso das táticas e estratégias de Gile pressupõe que o intérprete tenha uma mente ágil e perspicaz, fazendo escolhas constantemente quanto ao que é essencial, sempre engajado na solução de problemas. O intérprete precisa ter resiliência, mantendo até o fim a energia mental despendida nos esforços. Precisa ser alguém que gerencie diversas atividades mentais simultaneamente, tanto na interpretação consecutiva quanto na interpretação simultânea, demonstrando versatilidade e flexibilidade em sua maneira de expressar o sentido do discurso na língua de chegada. Essas e várias outras características muito bem-vindas no intérprete coincidem com as características de pessoas que possuem mentes criativas (TORRANCE \& TORRANCE, 1974).

Mas qual a relação entre a interpretação e a criatividade? Para responder tal pergunta, vejamos primeiro o que é criatividade. 


\section{O que é criatividade?}

A criatividade geralmente nos remete à arte: à criação do novo, do diferente; o acréscimo de novas ideias a algum conceito já existente. Associamos criatividade a um novo produto. Entretanto, a criatividade também pode ser entendida como um processo, e pessoas criativas podem ser encontradas nas mais diversas áreas de atuação, não só no meio artístico: há cientistas criativos, professores criativos, vendedores criativos. Vamos nos debruçar aqui sobre uma visão mais ampla da criatividade, que pode ser aplicada ao processo da interpretação, bem como às características do próprio intérprete.

De acordo com o dicionário Aurélio (2009),

Criatividade. S. f. 1. Qualidade de criativo. 2. Capacidade criadora; engenho, inventividade. 3. E. Ling. Capacidade que tem um falante nativo de criar e compreender um número ilimitado de sentenças em sua língua.

Engenho. S. m. 1. Faculdade inventiva; talento. 2. Habilidade, destreza. 3. Sutileza, argúcia. (...)

Argúcia. S. f. 1. Agudeza de espírito. 2. Sutileza de raciocínio ou de argumentação.

Sutil. Adj. 1. Tênue, fino, delgado, grácil. 2. Agudo, penetrante, fino. 3. Muito miúdo, quase impalpável. 4. Feito com delicadeza. 5. Que anda sem fazer rumor. 6. Fig. Perspicaz, hábil, engenhoso, talentoso. (...)

Hábil. Adj. 1. Que tem aptidão para alguma coisa. 2. Competente, apto, capaz. 3. Ágil de mãos e movimentos; destro. 4. Inteligente, esperto, sagaz, fino. (...)

Habilidade. S. f. Qualidade de hábil. Altas habilidades. Educ. Esp. Notável desempenho e elevada potencialidade em qualquer dos seguintes aspectos, isolados ou combinados: capacidade intelectual geral, aptidão específica, pensamento criativo ou produtivo, capacidade de liderança, talento especial para artes, e capacidade psicomotora.

Invenção. S. f. 1.Ato ou efeito de inventar, de criar, de engendrar. 2. Coisa nova criada ou concebida no campo da ciência, da tecnologia ou das artes. (...) 4. Faculdade ou poder inventivo; engenho, criatividade, inventividade, inventiva. 5. Novo meio ou expediente para alcançar um fim; criação, descoberta. (...)

Inventivo. Adj. 1. Inventor. 2. Em que há invenção ou engenho. 3. De imaginação viva.

(NOVO DICIONÁRIO AURÉLIO DA LÍNGUA PORTUGUESA, 2009) 
Segundo essas definições, a criatividade pode ser entendida como engenho, inventividade, destreza, argúcia; a capacidade de descobrir sutilezas e encontrar novos meios para alcançar um fim. A pessoa criativa é inventiva: tem imaginação viva e aguçada; é perspicaz, hábil, de raciocínio ágil.

A criatividade, assim, não só é bem-vinda como é essencial ao intérprete um profissional que trabalha com a tradução de um discurso oral, em tempo real, sob a pressão de tempo restrito, proferido uma única vez (ou seja, sem possibilidade de revisão), produzido no contexto de uma determinada situação e cultura. ${ }^{14}$ Sem dúvida, o intérprete precisa ter uma memória aguçada, um alto nível de energia mental (GILE, 2009). Precisa captar as sutilezas do que está sendo dito, somado às informações extralinguísticas, como linguagem corporal, "clima" da conferência, registro, tom de voz do orador, além de ter imaginação viva para a desverbalização, visualizando o sentido, sempre que possível (SELESKOVITCH, 1975). O intérprete precisa, ainda, ter inventividade para encontrar novos meios e soluções para problemas linguísticos ou culturais que possam surgir - quem nunca se deparou com o "intraduzível"? - como piadas, trocadilhos e provérbios populares, por exemplo. O intérprete precisa demonstrar engenho e habilidade ao lidar com o inesperado: elemento sempre presente no seu trabalho (TAYLOR-BOULADON, 2007).

\subsection{A criatividade como processo}

Maria Helena Novaes (1977) destaca quatro categorias para as definições de criatividade na psicologia:

Podemos enquadrar as diversas definições existentes em quatro categorias, as que dizem respeito: à pessoa que cria, enfatizando os aspectos de temperamento, traços, valores, atitudes emocionais; ao processo criador, destacando pensamento criativo, motivações, percepção; ao produto criado, analisando invenções, obras artísticas ou inovações científicas; e às influências ambientais, condicionamentos educativos, sociais e culturais. (p. 17, grifos no original)

Dentre as muitas facetas e definições de criatividade na vasta literatura existente no campo da psicologia, destacamos a criatividade como processo. Esse processo criador, conforme afirmou Novaes, envolve, dentre outros fatores, "o pensamento criativo, as motivações e a percepção" - elementos dos quais o

\footnotetext{
${ }^{14}$ Vide a definição de interpretação na página 1 , com base em elementos traçados por Pöchhacker (2004) e Kade (1968).
} 
intérprete precisa fazer bom uso no processo da interpretação. Seu pensamento é ágil, engenhoso; suas motivações precisam estar alinhadas com o tema proposto pelo orador, a fim de realizar o melhor trabalho possível; sua percepção precisa ser aguçada mediante qualquer mudança repentina de planos no decorrer do evento.

Ellis Paul Torrance $(1974)^{15}$, renomado teórico do tema da criatividade no campo da psicologia e conhecido por ter originado os Testes de Pensamento Criativo de Torrance $(\mathrm{TTCT})^{16}$, identificou quatro categorias gerais que o processo criativo envolve (TORRANCE, 1974 apud GRAN, 1998): fluidez (facilidade de gerar ideias); flexibilidade (diferentes estratégias para a solução de problemas); originalidade (oferecer respostas pouco comuns); e elaboração (desenvolver ideias com especificidades adequadas, esclarecer conceitos e reformular estruturas). Dentre as muitas características da criatividade como processo, Torrance salienta que:

Criatividade é um processo que torna alguém sensível aos problemas, deficiências, hiatos ou lacunas nos conhecimentos, e o leva a identificar dificuldades, procurar soluções, fazer especulações ou formular hipóteses, testar e retestar essas hipóteses, possivelmente modificando-as, e a comunicar os resultados. (TORRANCE, 1962 apud NOVAES, 1977, p.18) ${ }^{17}$

Dentre as principais características citadas por Torrance (1974), percebemos que a maioria delas se aplica, de uma maneira ou de outra, ao processo de interpretação. É necessário fluidez e rapidez para verter ideias em outra língua em tempo real e sem possibilidade de revisão; é necessário o uso flexível de estratégias para a solução de problemas - desde dificuldades em encontrar o melhor equivalente para a tradução de um termo específico num dado momento da conferência até imprevistos constantes durante o evento. É bem-vinda a originalidade, fornecendo soluções pouco comuns a esses mesmos problemas, e a elaboração já faz naturalmente parte do processo da interpretação, já que o intérprete trabalha com a constante reformulação de ideias de uma língua para outra, sempre adequando sua tradução a um determinado contexto e cultura. Ademais, conforme também mencionado por Torrance (1962 apud NOVAES,

\footnotetext{
${ }^{15}$ TORRANCE, E. P. Torrance Tests on Creative Thinking (TTCT). Lexington, MA: Xerox Education Company, 1974.

${ }^{16}$ Torrance Tests on Creative Thinking.

${ }^{17}$ TORRANCE, E. P. Guiding Creative Talent. Englewood Cliffs, New Jersey: Prentice-Hall, 1962.
} 
1977), o processo criativo demanda sensibilidade na solução das deficiências realidade que também faz parte da vida do intérprete diante de tamanha energia mental despendida e múltiplos esforços simultâneos (GILE, 2009).

Ildikó Horváth (2010), intérprete e professora de interpretação em Budapeste (Interpreter and Translator Training Department of Eötvös Lóránd University), elaborou e realizou uma pesquisa com 45 intérpretes que tinham pelo menos 5 anos de experiência. Sua pesquisa buscava traçar relações entre a criatividade e a interpretação, e seu curto questionário continha somente duas perguntas: 1) Você acha que a interpretação é uma atividade criativa? e 2) O que você acredita ser a criatividade? Para sua surpresa, dentre os 40 questionários respondidos e avaliados, 29 intérpretes entendiam seu trabalho como um ofício criativo, 5 não acreditavam que a atividade de interpretação envolvesse a criatividade e 6 acreditavam haver alguma restrição quanto a considerar sua atividade criativa.

A grande maioria entendia criatividade como um produto, e não um processo, o que foi considerado pela autora uma visão um tanto limitada do que vem a ser a própria criatividade. As especificações das respostas dos participantes evidenciavam características de processos, apesar de terem definido a interpretação como produto: foi citada a tomada de decisões, a necessidade de condensar a mensagem devido ao curto tempo para vertê-la, a utilização da cultura geral e das informações extralinguísticas para dar forma ao sentido na língua de chegada, a adequação da transferência da mensagem em dada circunstância, dentre outras (HORVÁTH, 2010). Entre os intérpretes que não consideravam seu trabalho um ofício criativo, um deles respondeu: "na interpretação, preciso reformular a criatividade do outro. Para isso, preciso de muitas coisas (...) menos de criatividade" (p. 153). Mas um dos intérpretes participantes da pesquisa que acreditava ser a interpretação uma atividade criativa definiu criatividade da seguinte forma, salientando o pensamento divergente:

No sentido psicológico, criatividade significa pensamento divergente: gera soluções únicas e novas em situações complexas e amplas. É caracterizada pela tolerância às contradições e por um alto grau de abertura e flexibilidade. A criatividade é uma força criadora e é acompanhada, na maioria das vezes, por uma 
habilidade de reagir rapidamente e por um estado intenso de preparação psíquica. $(\text { p. } 152)^{18}$

Uma das características do pensamento criativo, conforme entendido por alguns teóricos da psicologia, é o pensamento divergente. J. P. Guilford, em 1950, fez uma distinção interessante entre o pensamento convergente e o pensamento divergente em seu discurso diante da Associação Americana de Psicologia (APA, American Psychological Association). Guilford salientou que o pensamento convergente inclui seguir regras pré-estabelecidas para a resolução de problemas, enquanto o pensamento divergente envolve inúmeras possibilidades não elucubradas antes, gerando novas informações com base num dado colhido e uma variedade de produções possíveis a partir da mesma fonte (WITTIG \& BELKIN, 1990 apud HORVÁTH, 2010 ${ }^{19}$. O pensamento convergente está ligado a um método padronizado de resolução de problemas, geralmente oferecendo uma única solução correta dentro de um quadro previsível de passos, enquanto o pensamento divergente geralmente ocorre quanto ainda não há uma maneira clara para a resolução do problema, produzindo uma gama de soluções apropriadas (GUILFORD, 1950 apud KNELLER, 1985) ${ }^{20}$. Guilford (1950) também sinaliza alguns fatores presentes no pensamento divergente, dentre eles: fluência vocabular, flexibilidade semântica espontânea, flexibilidade figurativa espontânea, fluência associativa, flexibilidade simbólica adaptativa e elaboração (apud KNELLER, 1985).

O pensamento divergente envolve a capacidade de não se prender a ideias pré-concebidas, mas sim de "tentar sempre penetrar, perceber, delinear novas relações" (NOVAES, 1977, p. 52). Dentre os estudos realizados a fim de pesquisar traços da personalidade criativa, as produções divergentes do indivíduo se destacaram: a capacidade mental de abrir um prisma de opções incomuns para objetos e elementos comuns, como fazer associações remotas, elaborar planos, dar sentido a símbolos aparentemente sem sentido, ter a habilidade de redefinir situações, entre outros exemplos, enquanto o pensamento convergente envolve a redefinição simbólica e semântica (NOVAES, 1977). O pensamento divergente

\footnotetext{
${ }^{18}$ In a psychological sense creativity means divergent thinking. It leads to novel and individual solutions in complex and open situations. It is characterized by the tolerance of contradictions and a high degree of openness and flexibility. Creativity is a force to create, and is accompanied, most of the time, by an ability to react quickly and an intense state of psychic preparedness.

${ }^{19}$ WITTIG, A. F. \& BELKIN, G. S. Introduction to psychology. New York: McGraw-Hill, 1990.

${ }^{20}$ GUILFORD, J. P. Creativity. The American Psychologist, 1950, v.5, n.9, p. 444-454.
} 
tem relação, portanto, com a criatividade, que também pode ser entendida como a habilidade de formar novas combinações (MEDNICK, 1962 apud GRAN, $1998)^{21}$. Mais tarde em suas pesquisas, entretanto, Guilford vem a afirmar que as capacidades mentais que envolvem a criatividade não podem ser enquadradas somente na categoria de pensamento divergente, pois a criatividade também envolve a redefinição simbólica e semântica - pertencentes ao pensamento convergente - e a sensibilidade a problemas (KNELLER, 1985; TORRANCE, 1988 apud HORVÁTH, 2010²2; NOVAES, 1977).

O desempenho do intérprete é criativo quando envolve a utilização de seu conhecimento e experiência, não só combinando e reorganizando elementos de representações linguísticas comumente pensadas, mas reestruturando a frase na língua de chegada de modo muitas vezes inesperado e estando sempre aberto a novas adaptações durante a própria conferência, à medida que mais informações vão sendo acrescentadas (RICCARDI, 1998).

A criatividade na interpretação está justamente em ser esse um processo de comunicação de sentido - através do uso da entonação, do acompanhamento do ritmo do orador, da reformulação do discurso na língua de chegada de maneira adequada à conferência, - e não somente um processo de mera reprodução de informações (SELESKOVITCH, 1978). O intérprete precisa ser expressivo a fim de comunicar sentido, estimulando no ouvinte as reações pretendidas pelo orador, inclusive no que tange às emoções (NOVAES, 1977):

Criatividade implica basicamente em comportamento comunicativo destinado a transmitir alguma coisa a outras pessoas, diferindo essencialmente do comportamento informativo, na medida em que não pretende só transmitir informações, mas sim sentimentos, emoções e, por isso, é classificado de "expressivo". Expressar um sentimento significa produzir modificações na situação ambiental que irão funcionar como estímulos capazes de provocar no observador reações emocionais equivalentes. (p. 48)

Nesse processo comunicativo, expressivo e criativo que é a interpretação, há algumas evidências específicas de elementos da criatividade: a solução de problemas, a adequação ao contexto da conferência, a habilidade de se fazer novas

\footnotetext{
${ }^{21}$ MEDNICK, S. A. The associative basis of the creative process. Psychological Review, v.69, n.3, p.220-232, 1962.

${ }^{22}$ TORRANCE, E. P. The nature of creativity as manifest in testing. In: STERNBERG, R. J. (ed.). The nature of creativity: contemporary psychological perspectives. Cambridge: Cambridge University Press, 1988. p. 43-75.
} 
conexões e integrar as partes ao todo, a tomada de decisões de maneira ágil, a habilidade de reformular as informações de maneira adequada ao contexto da conferência, a reestruturação linguística na língua de chegada, a utilização correta de diversas estratégias de interpretação, o embasamento da preparação e da cultura geral que permite um maior leque de opções linguísticas, a desverbalização e a reestruturação linguística, entre outros exemplos, conforme veremos a seguir.

\subsection{A criatividade na interpretação}

Graham Wallas, teórico da psicologia social, foi o primeiro a distinguir, em 1926, as quatro fases do processo criador, conhecidas como: preparação, incubação, iluminação e verificação (KNELLER, 1985). Segundo Ildikó Horváth (2010), se aplicarmos as quatro fases propostas por Wallas à interpretação, certamente caberia comparar tal processo criador ao processo mais amplo da interpretação - começando pela fase da preparação para o evento, passando pela execução da interpretação durante o evento, até a avaliação do próprio desempenho do intérprete após o término do evento. Desse modo, seria possível compreender melhor as diferentes fases do processo criador, salientando suas interfaces com os diferentes momentos do processo mais amplo de tudo o que envolve a interpretação (antes, durante e depois do evento a ser interpretado).

A fase da preparação do processo criador, segundo Kneller (1985), é onde ocorre "rigorosa investigação das potencialidades da ideia germinal. O criador lê, anota, discute, indaga, coleciona, explora. Propõe possíveis soluções e pondera suas forças e fraquezas" (p. 63-64). Assim como o pintor, o artista, o poeta, o dançarino e o ator se preparam para seu trabalho de criação, o intérprete também passa pela fase de preparação para o evento a fim de se familiarizar com o assunto, de perceber possíveis problemas e dificuldades, de investigar todas as potencialidades em questão: Quem serão os oradores do evento? De que ponto de vista ideológico partem? Sobre o quê irão discursar? Quais são as traduções adequadas para os termos que provavelmente citarão em seu discurso? De que nacionalidade são? Têm sotaque? São conhecidos por falar rápido demais? Pretendem ler seu discurso? Na fase de preparação, o intérprete faz justamente o que foi descrito acima por Kneller: "lê, anota, discute, indaga, coleciona, explora". 
Graças à disseminação dos espaços virtuais, o intérprete também tem a possibilidade de assistir vídeos, muitas vezes de eventos similares, onde tem o privilégio de entrar em contato com a maneira própria do orador discursar. É nessa fase que o intérprete elabora um glossário específico para o evento, com os principais termos que podem surgir, já se adiantando com "soluções" para esses termos na língua de chegada.

A fase da incubação é o período em que "as ideias do criador são "enterradas"” (KNELLER, 1985, p. 66). É o momento em que há a assimilação das ideias colhidas, onde é possível amadurecer o assunto. Há poetas como Hart Crane, por exemplo, que se dedicava a um poema durante meses ou até anos, rabiscando alguns versos aqui e ali, carregando sempre um pedaço de papel no bolso, para quando viesse a inspiração. O intérprete também precisa de um período de amadurecimento das informações que colheu com sua preparação, quer seja decorando seu glossário, quer seja se aprofundando no assunto para entender melhor a lógica e a motivação por trás do discurso que será interpretado. $\mathrm{Na}$ grande maioria das vezes, o intérprete não dispõe de tanto tempo de incubação das informações colhidas, mas ainda que seja pouco o tempo de que dispõe, essa “incubação" faz-se necessária. Como afirma Kneller (1985), "não pode vir a inspiração sem o trabalho do inconsciente, seja por seis meses, seis horas ou seis minutos" (p. 67). Assim como o poeta, há vários intérpretes que sempre carregam um pequeno bloco à mão, para anotarem novos termos com os quais entram em contato todos os dias, que podem vir a ser úteis em futuros eventos que interpretarão.

Há interfaces entre a fase de iluminação do processo criador e o momento em que a interpretação está sendo executada: "o momento de iluminação leva o processo de criação a um clímax. De repente, o criador percebe a solução de seu problema - o conceito que enfoca todos os fatos, o pensamento que completa a cadeia de ideias em que ele trabalha" (KNELLER, 1985, p. 68). Quando o intérprete está bem preparado, ele experimenta a iluminação em seus processos mentais, durante a interpretação: faz conexões com as informações colhidas na preparação, usa todo o seu conhecimento disponível (cultura geral, preparação, conhecimento linguístico) a fim de concentrar-se na melhor maneira de traduzir o discurso, em tempo real. Assim como o artista ou o cientista se sentem no momento em que lhes sobrevém um precioso insight, o intérprete sente-se 
realizado quando consegue executar, com competência, sua tarefa. O próprio Charles Darwin, após reunir, por muitos anos, dados sobre a evolução das espécies, pôde um dia finalmente afirmar, em sua autobiografia: "posso lembrar o preciso lugar na estrada em que, (...) me ocorreu, para alegria minha, a solução" (KNELLER, 1985, p. 68). A realização do intérprete está em saber, no momento em que interpreta, que está fazendo um trabalho de qualidade, tendo como base sua preparação para o evento e experimentando diversos insights de soluções adequadas ao momento do evento.

A última fase do processo criador é a fase de verificação, também conhecida como revisão (KNELLER, 1985). Este é o momento em que a iluminação obtida a partir de toda a preparação é verificada, analisada e avaliada. Um poeta pode enviar seu trabalho a um ou dois especialistas, por exemplo, antes de publicar sua obra (p. 72). É o momento de refletir sobre a reação dos recipientes de seu trabalho, de obter feedback sobre o seu desempenho: "após identificar-se (...) com sua obra no momento de iluminação, o criador agora recua e imagina as reações daqueles com quem intenta comunicar-se" (p. 72). Após o evento, o intérprete crescerá como profissional ao aprender com a experiência: no que foi bemsucedido? O que poderia ter sido mais bem executado? O glossário foi útil? Quais outros termos podem ser acrescentados ao glossário para futuros eventos de temática similar?

Quanto ao processo de interpretação em si, apesar de ser defendido como um processo criativo por estudiosos como Ildikó Horváth (2010), Alessandra Riccardi (1998) e Laura Gran (1998), seria mais difícil identificar as quatro fases propostas por Wallas durante o momento em que a interpretação do discurso está em pleno curso. Alguns estudiosos, como Pselk (1996) ${ }^{23}$, chegam a afirmar que "o processo do pensamento criativo é uma linha de raciocínio integrada, que não se presta à segmentação subentendida nos passos de um modelo". ${ }^{24}$ (PSELK, 1996, p.1 apud HORVÁTH, 2010, p. 155). Apesar do processo criador não ser identificável em etapas no momento da interpretação, é certamente possível identificar pontos de convergência entre algumas características do pensamento

\footnotetext{
${ }^{23}$ PSELK, P.E. Working Paper: Models for the Creative Process. E. Pselk \& Associates, 1996. Disponível em: <http://www.directedcreativity.com/pages/WPModels.html>. Acesso em: 23/07/2008.

${ }^{24}$ the process of creative thinking is an integrated line of thought that does not lend itself to the segmentation implied by the steps of a model.
} 
criativo e os processos mentais que ocorrem durante a interpretação simultânea e consecutiva.

Horváth (2010) defende que o pensamento criativo envolve novas conexões, ou seja, ligar ideias que não estavam antes associadas umas à outras. A criatividade difere do pensamento analítico, pois requer o uso da imaginação para a obtenção de resultados a partir de diversas soluções possíveis. Novaes (1977) também afirma que a dimensão criadora "leva o indivíduo a fazer novas associações para integrar objetos e ideias e a saber manipular, de forma criativa, para ativar sua mente e descobrir novas potencialidades mentais" (p. 9). Segundo Alessandra Riccardi (1998), novas associações de informações linguísticas e extralinguísticas podem levar a níveis diferentes de criatividade. Na interpretação, é fundamental ter a percepção da relação das partes com o todo, característica do pensamento produtivo, conforme demonstrado pelo psicólogo Max Wertheimer, em 1945 (RICCARDI, 1998).

Há que se ter, na interpretação, a habilidade de condensar a informação ao máximo na língua de chegada, a fim de otimizar o tempo. Diferentemente da abstração de informações - uma relação mais analítica com o texto - ao condensar a informação, o intérprete precisa ter a capacidade de não só entender o que foi dito, mas também de verter esse mesmo sentido na forma mais sucinta possível, o que requer um processo criativo (GRAN, 1998, p. 155). Alessandra Riccardi (1998) afirma que na interpretação há a reestruturação do texto na língua de chegada em termos lexicais, sintáticos e semânticos. Quanto maior a reorganização da estrutura linguística, mais criativo será o processo. O discurso de chegada é um novo produto, apesar de se assemelhar ao discurso original em termos de conteúdo. Numa ampla gama de possibilidades, o desempenho pessoal de cada intérprete varia, pois cada um combinará ou reorganizará as informações na língua de chegada de acordo com seu conhecimento e experiência, com soluções mais ou menos comuns, demonstrando maior ou menor criatividade (RICCARDI, 1998).

Alessandra Riccardi (1998) ainda salienta que o desempenho criativo na interpretação é aquele que não é influenciado pela estrutura linguística da língua de partida. Ao contrário, o intérprete deve resistir à forma da língua de partida, a fim de não ser influenciado por ela, concentrando-se no sentido da mensagem (HORVÁTH, 2010). Foi isso o que Danica Seleskovitch (1978) propôs com a 
desverbalização na sua Teoria Interpretativa da Tradução: o intérprete deve ter a capacidade de não se apegar à literalidade no momento da interpretação, mas verter plenamente o sentido na língua de chegada de modo natural e adequado. Horváth (2010) ainda se arrisca a dizer que a interpretação é uma recriação, ou seja, a criação de um discurso numa outra língua - um novo produto, diferente do original.

Horváth (2010) cita Perkins (1988), teórico que afirma que a pessoa criativa produz resultados que aparentam originalidade e adequação. A adequação do discurso de chegada ao contexto da conferência é primordial, já que o intérprete se encontra sempre em um contexto cultural específico. A tradução comumente usada para uma determinada palavra, termo ou expressão pode ser completamente inadequada para a situação da conferência em que se está trabalhando. É também papel do intérprete ter a sensibilidade de identificar o que é adequado para um dado momento, o que vai fazer mais sentido na língua de chegada de modo que tenha o mesmo efeito e sentido propostos na língua de partida, e não somente uma tradução correta. Colin Martindale (1994) ${ }^{25}$, citado por Alessandra Riccardi (1998), afirma que uma ideia criativa é geralmente definida como uma ideia nova, útil ou adequada à situação em questão. O intérprete precisa lidar não só com a tradução do discurso na língua de chegada - as palavras a serem utilizadas - mas principalmente com a adequação dessa mesma tradução para o momento em que se encontra (ALEXIEVA, 1998).

J. Levý $(1967)^{26}$ identificou, como outros autores, ser a interpretação um processo de tomada de decisões: o intérprete se vê constantemente fazendo escolhas, em situações consecutivas, precisando escolher a melhor opção dentre várias alternativas (ALEXIEVA, 1998). O intérprete, tanto na interpretação simultânea quanto na interpretação consecutiva, precisa selecionar, por exemplo, quais informações traduzir imediatamente ou um pouco depois, quando o contexto ficar mais claro. Precisa também selecionar o que é essencial do que é supérfluo naquele dado momento, principalmente quando há um esgotamento mental devido à velocidade da fala do orador - típica situação de controle de danos na interpretação. Há que se escolher o quanto se distanciará do orador na

\footnotetext{
${ }^{25}$ MARTINDALE, Colin. How can we measure a society's creativity? In: BODEN, Margareth A. (ed.). Dimensions of Creativity. Cambridge: MIT Press, 1994. p. 159-197.

${ }^{26}$ LEVÝ, J. Translation as a decision process. In Honor of Roman Jakobson, v. II. Mouton: The Hague, 1967. p. 1171-1182.
} 
interpretação simultânea, ou o que valerá a pena anotar para não esquecer, na interpretação consecutiva, tendo em mente quais símbolos ou abreviações usar. Ludskanov (1971) salienta que a tradução sempre é uma atividade criativa, já que, em todas as suas formas, quer seja escrita ou oral, pressupõe um número de escolhas que não são pré-determinadas (LUDSKANOV, 1971 apud ALEXIEVA, $1988)^{27}$. Isso significa que o intérprete se vê, muitas vezes, diante de um amplo espectro de possibilidades.

A solução de problemas também foi identificada por diversos autores como um dos aspectos da criatividade. Szabó $(2002)^{28}$ afirma que os processos de pensamento criativo envolvem a solução de problemas de modo original e útil (SZABÓ, 2002 apud HORVÁTH, 2010). Tanto a solução de problemas quanto o pensamento criativo têm semelhanças: ambos exigem que o indivíduo crie e aplique novas estratégias. Um problema pode ser definido como um desvio da situação ideal (HORVÁTH, 2010). Como o intérprete precisa lidar constantemente com imprevistos e com o inesperado, precisa sempre fazer uso da criatividade a fim de solucionar o problema que se apresentar, qualquer que seja o desvio da situação ideal: desde o orador decidir mudar seu tema até ser surpreendido pela falta de recursos que normalmente teria. Um problema nos fones de ouvido dos participantes, por exemplo, pode levar o intérprete a precisar fazer uma interpretação consecutiva fora da cabine, ao invés de uma interpretação simultânea na cabine. No caso da interpretação consecutiva, apesar do intérprete já ter, preferivelmente, elaborado um método pessoal de anotações com símbolos e abreviações, a utilização desse mesmo método na prática exigirá dele a solução de diversas dificuldades que podem surgir no calor da situação (RICCARDI, 1998). A criatividade envolve saltos intuitivos e solução de problemas na combinação de ideias não comumente associadas (NOVAES, 1977). A solução de problemas é muito mais eficiente, no caso do intérprete, quando ele tem um conhecimento aprofundado do assunto em questão, através da cultura geral e da preparação. Desse modo, o conhecimento previamente adquirido tem um papel importante na criatividade, pois torna-se o embasamento para a solução adequada

\footnotetext{
${ }^{27}$ LUDSKANOV, Alexander. Prevezhdat chovekut i mashinata (Man and computer translation). In: PASKALEVA, Elena (ed.). Collected Works. Sofia: Narodna Kultura Publishing House, 1980.

${ }^{28}$ SZABÓ, E. Problémamegoldás és kreatív gondolkodás. Sopron: Euroqualitas Könyvkiadó, 2002.
} 
dos problemas que venham a surgir ao longo da conferência (HORVÁTH, 2010), como veremos mais adiante.

Partindo do pressuposto de que a interpretação é uma atividade onde há a constante solução de problemas, Alessandra Riccardi (1998) afirma que, de fato, a interpretação pode ser entendida como um processo criativo:

Se o processo de interpretação for considerado uma atividade de solução de problemas na qual o texto de partida é o problema e o texto de chegada é a solução, então se segue que é o procedimento da interpretação, o fato da interpretação ocorrer 'em tempo real', que leva a um processo criativo. A partir de um direcionamento limitado ou do desenrolar constante de diversos elementos, sem qualquer interrupção ou tempo maior do que alguns segundos para pensar, o intérprete deve chegar a uma conclusão correta ou ser capaz de antecipar a mensagem a ponto de organizar sua produção linguística corretamente. Ao fazê-lo, não está somente repetindo algo dito por alguém, mas está também engajado em um processo criativo ou produtivo. (p. 172)

Sendo a interpretação considerada um processo criativo por diversos autores dos Estudos da Tradução e da Interpretação, reflitamos sobre as características da personalidade criativa que podem se aplicar ao intérprete, a fim de contribuir para um melhor desempenho do seu trabalho.

\subsection{Características do intérprete criativo}

Há certas características encontradas em pessoas criativas, conforme postulam alguns teóricos da psicologia. Destacaremos algumas dessas características e habilidades atribuídas à personalidade criativa e veremos de que forma podem contribuir para a atividade da interpretação.

Guilford (1968 apud NOVAES, 1977) $)^{30}$ cita, dentre as habilidades encontradas nos indivíduos criadores, características como fluência, flexibilidade, originalidade e pensamento divergente. Maria Helena Novaes (1977) menciona que há vários critérios utilizados para avaliar a criatividade em testes psicológicos,

\footnotetext{
${ }^{29}$ If the interpreting process is considered a problem-solving activity where the source-text is the problem and the target-text the solution, then it follows that it is the interpreting mode, the fact that interpreting is 'on-line', that leads to a creative process. From a limited set of cues or elements constantly unfolding, with no interruption or thinking longer than a few seconds, the interpreter has to come to a correct conclusion or be able to anticipate the message in such a way that he can organize his language output correctly. In doing so, s/he is not simply repeating something said by somebody else, but also engaging in a creative or productive process.

${ }^{30}$ GUILFORD, J. P. Intelligence, creativity and their educational implications. S. Diego: R. Knapp, 1968.
} 
dentre eles destacam-se: "sensibilidade para problemas, fluência, flexibilidade, originalidade, habilidade para redefinir situações, capacidade de análise e de síntese, coerência de organização" (p. 35). Conforme previamente citado, Laura Gran destaca que Torrance (1974 apud GRAN, 1998) identificou quatro categorias principais presentes no processo criativo, que coincidem com algumas das características citadas por Guilford (1968) e Novaes (1977): fluidez, flexibilidade, originalidade e elaboração. O intérprete precisa ser fluente, tendo um rápido comando da língua-alvo e traduzindo a informação de maneira fluida e compreensível. A flexibilidade precisa também estar sempre presente, pois o orador pode escolher mudar o rumo do discurso a qualquer momento, e o intérprete precisa continuar a acompanhar sua linha de raciocínio. Soluções originais para problemas linguísticos ou contextuais são sempre bem-vindas, apesar de não ser condição sine qua non no seu trabalho. $O$ pensamento divergente e a sensibilidade para problemas são importantes tanto para a solução de dificuldades linguísticas quanto para a percepção aguçada do que ocorre no ambiente de trabalho. O intérprete precisa verificar se o som está funcionando bem, se é possível enxergar a projeção da apresentação do orador, se foram disponibilizados fones de ouvido para que o orador possa interagir com os participantes no momento em que o mestre de cerimônias abrir para perguntas, dentre uma série de outros detalhes que estão além da função específica da tradução oral da palestra. A habilidade para redefinir situações, a capacidade de análise e de síntese, a coerência e a organização são vitais para o delivery, o discurso traduzido pelo intérprete. $\mathrm{O}$ intérprete precisará reestruturar a frase para que faça sentido na língua de chegada, se preciso, sintetizando a mensagem devido à restrição de tempo. A coerência e a organização precisam ser evidentes para o ouvinte, que, ao ouvir a mensagem na língua de chegada, deve ter a sensação de que o discurso soa tão natural quanto se o próprio orador falasse a sua língua.

Ildikó Horváth (2010) salienta que a criatividade também pode ser entendida como a capacidade de adaptar-se a novas situações, ambientes e circunstâncias, ou seja, responder de maneira adaptativa é uma característica da pessoa criativa. Kovács (1987) afirma que diversos estudos verificaram que "pessoas criativas têm uma atitude aberta, flexível e perceptiva, e estão sempre prontas a mudar seu ponto de vista. Há evidências de seu processamento mais 
rápido de informações" (KOVÁCS, 1987, p. 49 apud HORVÁTH, 2010, p. $150)^{31}$. Parece também haver uma relação entre a criatividade e situações frustrantes. A pessoa criativa tem características que lhe permitem lidar melhor com a frustração, reduzindo seu impacto (KAKAS, 1987 apud HORVÁTH, 2010) ${ }^{32}$. Ildikó Horváth (2010) chama atenção para o fato de que o contexto de trabalho do intérprete muda a cada evento. As novas características de cada trabalho, as condições únicas de cada situação — inclusive as personalidades e motivações dos participantes - exigem do intérprete flexibilidade e espontaneidade, que estão intimamente ligadas à criatividade. É necessário não somente adaptar-se às situações, mas reagir a elas de maneira construtiva (TORRANCE, 1988 apud HORVÁTH, 2010). Em estudos experimentais, pessoas criativas demonstraram estar mais abertas a estímulos e tiveram desempenho superior a outros em situações adversas, já que foram capazes de identificar estímulos neutros com maior precisão e velocidade (KOMLÓSI, 1987 apud HORVÁTH, 2010) ${ }^{33}$.

George Kneller (1985) também evidencia alguns traços de pessoas criativas. Pessoas criativas se apercebem mais de seu meio, têm sensibilidade aguçada e “experimentam" seu ambiente mais que outros, principalmente no que tange a detalhes como cores, texturas e reações. A pessoa criativa é mais fluente, tanto no sentido de produzir mais ideias quanto no sentido de ser mais articulada do que as outras na expressão verbal. A pessoa criativa é flexível, tentando sempre várias abordagens e novos usos para coisas comuns. Os criativos também são persistentes: sua criatividade muitas vezes passa por muitos obstáculos, sendo sustentada por longos períodos de tempo, até que suas ideias possam ser comprovadas. Pessoas criativas são curiosas: gostam de explorar ideias pelo simples prazer de obter conhecimento e "brincar" com elas (KNELLER, 1985). Maria Helena Novaes (1977) também destaca, dentre as características básicas do comportamento criativo: receptividade à estimulação do meio-ambiente, possibilidade de recolhimento ou imersão interna, capacidade de imaginação e

${ }^{31}$ KOVÁCS, Á. Creativity of associations given to complex and simple figures in groups of different preference. In: KARDOS, L., PLÉH, C. \& BARKÓCZI, I. (eds.). Studies in creativity. Budapest: Akadémiai Kiadó, 1987. p. 49-68.

${ }^{32}$ KAKAS, G. B. Study of the relationship between creativity and frustration tolerance. In: KARDOS, L., PLÉH, C. \& BARKÓCZI, I. (eds.). Studies in creativity. Budapest: Akadémiai Kiadó, 1987. p. 79-86.

${ }^{33}$ KOMLÓSI, A. Creativity and perception. In: KARDOS, L., PLÉH, C. \& BARKÓCZI, I. (eds.). Studies in creativity. Budapest: Akadémiai Kiadó, 1987. p. 11-22. 
julgamento, espírito de indagação e curiosidade, uso adequado e proveitoso dos erros e amplitude e fertilidade de abordagens.

Características como adaptabilidade, percepção aguçada, receptividade a estímulos, persistência, curiosidade, uso proveitoso dos erros e fertilidade de abordagens são desejáveis no intérprete. Por lidar com uma atividade de tradução oral em tempo real, sob a pressão de tempo restrito, numa determinada situação e cultura, uma única vez, essas características ajudariam o intérprete a lidar melhor com os diversos estímulos, pressões e frustrações tão próprias do seu ofício. O intérprete é um eterno curioso: a informação é imprescindível para o aumento de sua cultura geral e de dados preciosos na fase de preparação para o seu trabalho. Aprender a lidar com seus erros e a crescer por meio da ampliação de abordagens possíveis pode auxiliar muito no seu desenvolvimento profissional. Quanto à persistência, a carreira da interpretação oferece muitos obstáculos, tanto no início, na tentativa de inserção no mercado por parte dos intérpretes iniciantes, quanto na sazonalidade da atividade para os mais experientes. Segundo Maria Helena Novaes (1977), “o indivíduo criativo caracteriza-se pela persistência de suas motivações e pela intensidade dos motivos que o levam a superar obstáculos e a vencer barreiras" (p. 90).

Torrance (1988) afirma que a essência da pessoa criativa é amar o que faz, o que torna possível outras qualidades, como coragem, independência de pensamento, honestidade, perseverança, curiosidade, disposição de correr riscos (TORRANCE, 1988 apud HORVÁTH, 2010). Maria Helena Novaes (1977) inclui o seguinte quadro no capítulo 5 , sobre os aspectos motivacionais da criatividade:

\begin{tabular}{|l|l|l|l|l|}
\hline $\begin{array}{c}\text { Propriedades } \\
\text { do processo } \\
\text { criativo }\end{array}$ & $\begin{array}{l}\text { Padrões de } \\
\text { julgamento }\end{array}$ & $\begin{array}{c}\text { Respostas } \\
\text { estéticas }\end{array}$ & $\begin{array}{l}\text { Qualidades } \\
\text { pessoais }\end{array}$ & $\begin{array}{c}\text { Predisposições } \\
\text { para estilos } \\
\text { cognitivos }\end{array}$ \\
\hline $\begin{array}{l}\text { - Originalidade } \\
\text { - Adequação } \\
\bullet \text { Transformação } \\
\bullet \text { Condensação }\end{array}$ & $\begin{array}{l}\bullet \text { Normas } \\
\bullet \text { Contexto } \\
\bullet \text { Limitação } \\
\text { Síntese }\end{array}$ & $\begin{array}{l}\bullet \text { Surpresa } \\
\bullet \text { Satisfação } \\
\bullet \text { Estimulação } \\
\bullet \text { Deleite }\end{array}$ & $\begin{array}{l}\bullet \text { Original } \\
\bullet \text { Sensitivo } \\
\bullet \text { Flexível } \\
\bullet \text { Poético }\end{array}$ & $\begin{array}{l}\text { Tolerância para } \\
\text { a incongruência } \\
\text { e inconsistência } \\
\bullet \text { Analítico e } \\
\text { intuitivo } \\
\bullet \text { Abertura } \\
\text { cognitiva } \\
\text { Reflexivo e } \\
\text { espontâneo }\end{array}$ \\
& & & & \\
\hline
\end{tabular}


(NOVAES, 1977, p. 92)

O quadro acima ilustra tanto algumas características do processo criativo quanto algumas características da pessoa criativa e de seu comportamento, características essas que, interessantemente, coincidem com características desejáveis em intérpretes. Quanto às propriedades do processo criativo, conforme salientadas no quadro, já mencionamos a importância e relevância da adequação, condensação de informações e originalidade dentro de uma ampla gama de possibilidades. Sobre os padrões de julgamento, o intérprete lida com normas o tempo inteiro - normas da língua de partida e de chegada, normas da conferência, regras subentendidas de comportamento na cabine - e precisa sempre estar atento ao seu contexto, tanto linguístico quanto extralinguístico. Quanto à limitação e ao poder de síntese, o intérprete tem sempre que lidar com a limitação do tempo e a delimitação do assunto do evento e seu poder de síntese precisa ser aguçado face aos seus desafios linguísticos no curto espaço de tempo de que dispõe. Quanto às respostas estéticas, o intérprete pode vir a experimentar reações como as supracitadas - surpresa, satisfação, estimulação e deleite - pois sua rápida estimulação mental gera nele, muitas vezes, um pico de adrenalina. Quanto às qualidades pessoais, ter os sentidos aguçados e ser flexível, por exemplo, são características quase indispensáveis ao intérprete, pois, conforme já mencionamos, mudanças repentinas e imprevistos geralmente são a regra, e não a exceção, nos eventos em que trabalha. E quanto às predisposições para estilos cognitivos, o intérprete também precisa lidar com a incongruência e a inconsistência. Nem todas as palestras farão sentido para ele, nem sempre o orador é consistente em tudo o que diz, nem sempre a linha de raciocínio é clara. O intérprete precisa ter abertura cognitiva e espontaneidade ao lidar, constantemente, com o novo e o desconhecido, buscando sempre o equilíbrio entre ser analítico e intuitivo, reflexivo e espontâneo.

Não só as pessoas criativas demonstram ter certas características e habilidades, mas as pessoas que têm atitudes criadoras também. Ter uma atitude criadora relaciona-se a ter interesses criativos, a estar envolvida em atividades que geram novas ideias e desenvolvem a crítica construtiva, relaciona-se à aquisição de conhecimento em novos campos, aguçando a sensibilidade através de estímulos do meio (NOVAES, 1977). Pode-se ainda afirmar que a atitude criadora 
tem relação com a produtividade (NOVAES, 1977). Segundo Maria Helena Novaes, "É possível o indivíduo ter atitudes criadoras, sem estar comprometido com atividades de criatividade ou produtos originais." (NOVAES, 1977, p. 40). Há pesquisas tanto sobre a atitude criadora quanto sobre a produtividade criativa. Barron (1963), por exemplo, verificou, através de um questionário de investigação de experiências, que

indivíduos produtivos criadores tendem a ser mais extrovertidos, entusiasmados, rápidos, fantasistas, tendo interesses teóricos e acadêmicos pela novidade nos acontecimentos e apresentam abertura e receptividade interna, (...) já os que têm predomínio de atitudes criadoras estão sempre se atualizando, expressam-se bem no seu comportamento externo e têm prazer em controlar as suas experiências. (NOVAES, 1977, p. 41).

Torrance (1962) desenvolveu um inventário a fim de medir atitudes face à criatividade. O resultado obtido foi: os alunos que apresentaram pontuação elevada relativa às atitudes criadoras tiveram melhor desempenho (apud NOVAES, 1977). Ter uma atitude criadora, portanto, só tem a contribuir com o desempenho do intérprete, pois se trata de uma atitude que, muitas vezes, pode ter relação com a motivação (NOVAES, 1977). Ainda segundo Novaes (1977), "as atitudes criativas levam o indivíduo a uma maior (...) autoconfiança, estimulandoo a desenvolver suas aptidões (...) [e] a conhecer suas características individuais e seus próprios limites" (p. 49).

Valerie Taylor-Bouladon (2007) lista, dentre os pré-requisitos para tornar-se intérprete de conferências, características como: intuição, pensamento ágil, capacidade de adaptação imediata a diversas situações, alto nível de concentração, rápida apreensão de sentido, excelente memória e grande curiosidade intelectual. Ildikó Horváth (2010) defende que o fenômeno da criatividade na interpretação pode e deve ser visto de modo mais amplo, já que mesmo os intérpretes experientes entrevistados por ela demonstraram uma visão um tanto limitada do assunto, relacionando a criatividade em seu trabalho somente a soluções linguísticas. A autora ainda se arrisca a afirmar que seria proveitoso investigar até que ponto a criatividade do intérprete poderia fornecer um prognóstico com relação à sua aptidão para a interpretação e ao seu sucesso profissional. A 
interface entre a criatividade e a interpretação, portanto, merece um estudo mais aprofundado (HORVÁTH, 2010).

A criatividade, entretanto, não substitui a preparação do intérprete para a conferência. O intérprete deve estar sempre bem-informado e ter ampla cultura geral, que será armazenada em sua memória e ativada mediante os diferentes assuntos que vier a interpretar. Conforme já mencionamos, o conhecimento prévio do intérprete tem papel fundamental para a própria utilização da criatividade. A preparação e a cultura geral do intérprete, juntamente com o contexto da conferência, dão direção ao sentido proposto pelo orador. Para a compreensão das "unidades de sentido" (LEDERER, 1978), é necessária a associação das palavras ouvidas à memória cognitiva, onde estão armazenadas informações prévias, de modo que a preparação e a cultura geral funcionam como a base para o surgimento de soluções criativas no processo da interpretação, como veremos em seguida.

\subsection{A cultura geral e a preparação no processo criativo}

A cultura geral, a preparação, o conhecimento linguístico, as informações extralinguísticas e o conhecimento adquirido e acumulado ao longo da própria conferência também têm um papel importante no processo criativo. É justamente o conhecimento prévio que possibilita escolhas linguísticas adequadas na interpretação. O conhecimento individual de cada intérprete levará à ativação de representações linguísticas em sua mente, o que possibilitará níveis diferentes de desempenho criativo na interpretação, dependendo da profundidade do conhecimento prévio. A cultura geral ajuda na desambiguação de possíveis significados e é útil na integração de diferentes orientações linguísticas (RICCARDI, 1998), afinal, é o contexto que dá sentido a palavras isoladas e o campo semântico tem papel primordial na dedução do sentido (SELESKOVITCH, 1975). O contexto tem papel semelhante à cultura geral, pois o trabalho do intérprete consiste em compreender bem ideias e transmiti-las, sendo a habilidade linguística um mero pré-requisito (SELESKOVITCH, 1978). Mas o próprio contexto só poderá ser bem compreendido mediante estudo prévio por parte do intérprete. 
Danica Seleskovitch (1978) e Marianne Lederer (1990 apud FREIRE, 2008), falam dos complementos cognitivos necessários para a compreensão da mensagem por falantes e ouvintes. São os complementos cognitivos - e não somente o conhecimento linguístico dos idiomas falados — que tornam possível a compreensão do campo semântico associado às palavras, pois a comunicação é realizada por meio dos elementos linguísticos somados ao contexto verbal, situacional e cognitivo, além da cultura geral.

Em pesquisas sobre o tema da criatividade, identificou-se o papel do conhecimento prévio ao lidar com o novo (HORVÁTH, 2010). Já que o intérprete se depara com o novo repetidas vezes - quer sejam novas palavras, novos assuntos ou novas situações durante a conferência - o conhecimento prévio e a atenção às informações linguísticas e extralinguísticas durante a conferência são essenciais, sendo elementos facilitadores do uso da criatividade no processo da interpretação. Maria Helena Novaes (1977) exemplifica como uma atitude criativa pode facilitar a adequação diante de novas informações:

uma atitude criativa representa uma resposta adequada a uma situação nova e uma resposta mais adequada e construtiva a uma situação antiga, devendo o indivíduo criador ser capaz de modificar seu comportamento em resposta a novas informações. (p. 48)

Em geral, o intérprete não tem a mesma compreensão do assunto que o público para quem interpreta, o que só aumenta sua responsabilidade. O conhecimento prévio permite ao intérprete uma maior segurança, reduzindo as hesitações ao fazer escolhas adequadas no momento da conferência. Mediante imprevistos, será mais fácil para o intérprete fazer uso de características como a flexibilidade e a fluidez quando está bem embasado no tema do evento, podendo até criar expectativas sobre o discurso do próximo orador, antecipando seu conteúdo (RICCARDI, 1998).

O intérprete precisará se valer de todo o seu conhecimento - sua história de vida, sua cultura geral, sua preparação para o evento, sua percepção das informações extralinguísticas da conferência - como complementos cognitivos para a compreensão da mensagem que irá transmitir, o que possibilita o uso criativo, inventivo e engenhoso de estratégias de interpretação na solução de problemas (HORVÁTH, 2010; RICCARDI, 1998). Maria Helena Novaes (1977) 
também fala sobre a relação entre a capacidade criadora e as experiências prévias e o conhecimento do indivíduo:

As capacidades criadoras e as suas habilidades efetivas dependerão da riqueza das experiências do indivíduo em áreas relevantes e das interconexões na sua rede neural, daí a importância do conhecimento organizado no processo criador e das experiências interligadas no campo. (p. 36)

Assim, a criatividade no processo da interpretação não anula a preparação e a cultura geral. Muito pelo contrário - é justamente o conhecimento armazenado em sua memória cognitiva que permite a utilização da criatividade. $\mathrm{O}$ intérprete deve se preparar para o ambiente onde ocorrerá a conferência, o assunto da conferência, os oradores, os tipos de discurso que serão proferidos, o nível de formalidade do evento e o vocabulário utilizado nas línguas de trabalho, para que, no momento necessário, possa fazer uso adequado da criatividade, seja pela utilização de estratégias criativas ou pela demonstração de características da personalidade criativa, como a adaptabilidade e a espontaneidade (RICCARDI, 1998; HORVÁTH, 2010).

Mas o que fazer quando não se tem, naturalmente, características da personalidade criativa, tão úteis no processo da interpretação? Pode-se ensinar a pensar de modo criativo?

\subsection{O potencial criativo universal}

E. Paul Torrance e J. Pansy Torrance (1974) desenvolveram diversos estudos experimentais na área do pensamento criativo. Um de seus experimentos abrangeu crianças entre 6 e 13 anos, alunos de artes em atividades curriculares ou extracurriculares, como a dança e as artes plásticas, incluindo a escultura e a pintura. Seu objetivo era ensinar as crianças a pensar criativamente através de oficinas que envolviam a solução criativa de problemas, a redação criativa e o movimento criativo. Houve a aplicação dos Testes de Pensamento Criativo de Torrance antes e depois do experimento, a fim de se documentar o progresso estatisticamente significativo das crianças, que chegou a uma média de $81 \%$. Seus mestres confirmaram uma melhora no envolvimento das crianças com os estudos, um aumento de sua curiosidade inata, habilidades de persistência, capacidade de lidar melhor com o fracasso e recomeçar, além de se tornarem mais sensíveis e 
humanos em todo o processo, desenvolvendo atitudes mais positivas em relação ao estudo, de modo geral (TORRANCE \& TORRANCE, 1974).

O Dr. e a Dra. Torrance (1974) também desenvolveram estudos experimentais na categoria de programas de leitura e de recursos com o objetivo de apoiar a leitura nas escolas, obtendo sucesso de 78\%. O programa mais bemsucedido foi o Programa de Leitura 360 (Reading 360), pois é o único programa para o qual há uma avaliação da eficiência do desenvolvimento da criatividade (NASH \& TORRANCE, 1970 apud TORRANCE \& TORRANCE, 1974) ${ }^{34}$. Algumas estratégias foram desenvolvidas pelo Dr. Paul Torrance para serem aplicadas antes, durante e depois dos exercícios de leitura. Antes da leitura, os participantes devem enfrentar ambiguidades e dúvidas, aumentar a expectativa e a antecipação, olhar o mesmo fato de pontos de vista diferentes, tentar fazer previsões a partir de um número limitado de informações e encorajar-se mutuamente a dar um passo à frente a partir do que já é conhecido. Durante a leitura, os participantes aumentam seu interesse pelo problema, pesquisam os elementos ausentes e trazem à tona as possibilidades de maneira sistemática, fazem a justaposição de elementos aparentemente irrelevantes ou não relacionados, exploram e examinam enigmas e encorajam-se na visualização de fatos. Após a leitura, os alunos terão que jogar com ambiguidades e incertezas, aprofundar-se e encorajar-se na pesquisa "além do óbvio" e transformar ou reformular informações ou outros elementos (TORRANCE \& TORRANCE, 1974). É interessante notar que vários desses exercícios e estratégias poderiam ser aplicados ao processo da interpretação — antes, durante e depois do evento a ser interpretado - e são exercícios bastante acessíveis, que todos podem praticar.

Os Torrance (1974) chegaram a definir o processo criativo "como um processo natural nos seres humanos” (p. 2), mas após diversas experiências,

tornou-se óbvio que alguns tipos de exercícios de aquecimento e alguns reforços positivos afetaram os resultados, aumentando a possibilidade do pensamento criativo ocorrer. (...) Um exame da definição do processo do pensamento criativo apresentada pelos autores indica que um certo número de habilidades são necessárias para tornar o processo bem sucedido. (...) Todas estas habilidades exigem prática e podem ser desenvolvidas através do ensino. (p. 3)

\footnotetext{
${ }^{34}$ NASH, W. R. \& TORRANCE, E. P. A preliminary evaluation of the effects of reading 360 on creative development and functioning at the first grade level. Athens, GA: Geórgia Studies of Creative Behavior, 1970.
} 
É importante ressaltar, entretanto, que tais exercícios e estratégias podem aumentar a probabilidade do desenvolvimento da criatividade, mas não podem garanti-lo (TORRANCE \& TORRANCE, 1974).

Maria Helena Novaes (1977) também defende que "todos os indivíduos têm potencial criador, podendo desenvolvê-lo em diversos níveis de intensidade" (p. 51). O comportamento criativo pode ser estimulado pelo meio $\mathrm{e}$ as potencialidades criadoras podem ser incentivadas e reforçadas pelo pensamento divergente, por abordagens não-diretivas, pela aprendizagem, pela descoberta, pela crítica construtiva, pela abertura para novas experiências, pelo desenvolvimento da habilidade de manipular conceitos e elementos diversos (NOVAES, 1977). A abordagem psicométrica, por exemplo, pressupõe que todo indivíduo é criativo e se concentra nas diferenças individuais relativas à criatividade (HORVÁTH, 2010). Várias tentativas e abordagens já foram criadas a fim de se medir a criatividade nos indivíduos, geralmente tendo como objetivo avaliar soluções únicas ou novas aos problemas que se apresentam (WITTIG \& BELKIN, 1990 apud HORVÁTH, 2010). Osborn (1988) 35 também destaca que a energia mental do indivíduo é um fator mais decisivo para o potencial criativo do que o talento inato, partindo do pressuposto que a criatividade pode ser desenvolvida, ensinada e testada (OSBORN, 1988 apud HORVÁTH, 2010).

Chegamos à conclusão, portanto, de que a criatividade pode ser entendida como um dos principais aspectos da interpretação. Ao nos aprofundarmos no conhecimento sobre a criatividade, também nos aprofundamos no conhecimento sobre a própria interpretação (HORVÁTH, 2010). Bistra Alexieva (1998) chega a afirmar que a criatividade por parte do intérprete é condição sine qua non para que a comunicação seja possível. Levando em consideração o potencial criativo universal, podemos buscar o desenvolvimento e o estímulo da criatividade nas diversas esferas em que atua o intérprete, quer seja em seus processos mentais ou em seu comportamento e personalidade.

O uso criativo de estratégias de interpretação também compõe o processo da interpretação (RICCARDI, 1998). Estratégias precisam ser utilizadas por diversas razões, como a sobrecarga da memória de trabalho ou o esgotamento da

\footnotetext{
${ }^{35}$ OSBORN, A. F. Créativité. L'imagination contructive (Traduction de l'ouvrage em langue anglaise publié sous Le titre Applied imagination par Charles Scribner's Sons, New York). Paris: Bordas, 1988.
} 
capacidade de processamento cognitivo disponível para realizar alguns dos esforços, conforme postulado por Daniel Gile (2009). As estratégias são úteis para lidar com elementos que podem prejudicar o desempenho do intérprete, buscando maximizar seu desempenho no menor tempo possível, conforme veremos no próximo capítulo. 


\section{Estratégias de interpretação e seu uso criativo}

Tanto na interpretação simultânea quanto na interpretação consecutiva, o intérprete se utiliza de estratégias para lidar com dificuldades específicas que pode vir a encontrar. Como se trata de uma atividade de tradução oral em tempo real, a pressão do tempo está sempre presente. O intérprete também se encontra em um determinado contexto cultural, precisando traduzir o discurso de modo a reproduzir o mesmo sentido e, sempre que possível, gerar nos participantes os mesmos efeitos pretendidos pelo orador na língua de partida (PÖCHHACKER, 2004). Dependendo da dificuldade, o intérprete se utiliza de estratégias baseadas em habilidades ou estratégias baseadas no conhecimento (REASON, 1990 apud RICCARDI, 1998) ${ }^{36}$.

As estratégias baseadas em habilidades são estratégias de respostas mais automatizadas, pois se aplicam a situações rotineiras, típicas de conferências ou reuniões, como: dar as boas vindas, apresentar palestrantes, agradecer pela presença dos convidados, demarcar os pontos de discussão da palestra e abrir para perguntas (RICCARDI, 1998). As estratégias baseadas no conhecimento, por outro lado, são estratégias que "entram em jogo" em novas situações, nas quais as respostas do intérprete são planejadas no momento em que surgem, fazendo uso de processos analíticos conscientes e tendo como base o conhecimento prévio a fim de serem utilizadas. As estratégias baseadas no conhecimento se aplicam a momentos em que a memória de trabalho e a capacidade cognitiva são limitadas, já que o intérprete precisa assimilar e reformular novas informações. As estratégias, portanto, aliviam a sobrecarga cognitiva, reduzindo alguns esforços e permitindo que o desempenho do intérprete não seja comprometido (GILE, 1997; RICCARDI, 1998).

Destacaremos, a seguir, algumas das diversas estratégias e técnicas utilizadas por intérpretes a fim de manter a qualidade do seu trabalho, tanto na modalidade simultânea quanto na modalidade consecutiva.

\subsection{Reformulação}

A reformulação é a ferramenta utilizada pelo intérprete para transmitir o sentido da mensagem proferida, geralmente numa estrutura linguística diferente

\footnotetext{
${ }^{36}$ REASON, James. Human Error. Cambridge: University Press, 1990.
} 
da estrutura da língua de partida. Muitas vezes não há, na língua de chegada, uma palavra ou expressão equivalente àquela utilizada pelo orador. $\mathrm{O}$ intérprete precisará, assim, reformular a frase, ou seja, reestruturá-la de modo a comunicar o sentido de uma maneira compreensível e natural na língua de chegada (JONES, 2002; GRAN, 1998). Um exemplo adaptado do exemplo que Roderick Jones (2002) fornece, seria a tradução da frase "he swam across the river" (p. 82). Uma tradução mais literal para o português poderia ser "ele nadou para o outro lado do rio", que não é uma tradução natural. Uma melhor tradução, nesse caso, seria: "ele atravessou o rio a nado". O sentido do que o orador quis dizer permanece, mas a frase é reformulada para acomodar esse sentido da melhor maneira possível na língua de chegada $\mathrm{O}$ intérprete fará melhor uso da técnica de reformulação se mantiver certa distância do orador (JONES, 2002).

O fato de a interpretação ser realizada em tempo real faz com que o intérprete não tenha a possibilidade de revisão do seu discurso (PÖCHHACKER, 2004). Por isso, principalmente na modalidade simultânea, a interpretação deve ser o mais sucinta possível, a fim de poupar tempo (JONES, 2002). O intérprete precisará estruturar a frase enquanto pronuncia a reformulação do discurso, fazendo os ajustes necessários, do modo mais adequado de acordo com a situação. Uma das estratégias de reformulação é, por exemplo, transformar orações subordinadas em orações coordenadas, a fim de ter mais liberdade no uso dos elementos de ligação entre as frases, deixando-as mais abertas a outras possibilidades, principalmente quando a linha de raciocínio do orador não está clara ou quando é difícil prever o restante da mensagem (RICCARDI, 1998). Laura Gran (1998) cita David Snelling (1992), que estuda maneiras mais eficazes de fazer a reformulação no caso das línguas latinas para o inglês. Snelling enfatiza a necessidade da utilização de diferentes abordagens na reformulação, não só levando em consideração o par linguístico, mas também a língua de chegada — se a tradução será feita para uma língua estrangeira ativa do intérprete ou para a sua língua nativa.

\subsection{A "Técnica do Salame"}

A fim de lidar com a restrição de tempo, o que o intérprete deve fazer quando o orador divaga, com frases longas a complicadas? A "técnica do salame" 
consiste em dividir frases muito longas numa série de frases mais curtas, utilizando elementos de ligação entre elas conforme for apropriado. Dessa maneira, o intérprete estaria "fatiando" a frase, como se costuma fazer com o salame, daí o nome de "técnica do salame" (JONES, 2002).

Daniel Gile (1997) recomenda, dentre as estratégias e táticas de interpretação, a divisão do discurso em "unidades" menores, para evitar o esgotamento da energia mental disponível. Alessandra Ricardi (1998) também defende que dividir frases longas em orações menores na língua de chegada previne a sobrecarga da memória de trabalho.

\subsection{Economia de palavras e omissão}

Há situações críticas, em que a palestra é muito densa, o orador se expressa em frases muito complexas, tem fala acelerada demais ou lê um texto escrito em alta velocidade. Nesses casos, é necessário que o intérprete mantenha maior distância do orador e concentre suas energias na análise e compreensão do discurso, economizando suas palavras ao máximo a fim de exprimir ao máximo o sentido do orador no menor tempo possível, e, se preciso, omitindo elementos menos importantes (JONES, 2002; RICCARDI, 1998). Nesse tipo de situação, se o intérprete não fizer uso de estratégias como a técnica do salame, a simplificação e a generalização, por exemplo, acabará "apostando corrida" com o orador, tendo menos tempo para processar a informação e vertendo uma tradução mais literal, o que está longe de ser desejável (JONES, 2002). O intérprete precisa ter muita energia mental e percepção aguçada para fazer as melhores escolhas ao selecionar o que é essencial à comunicação, dependendo das circunstâncias (ALEXIEVA, 1998). Nesses casos, geralmente é dada prioridade a proposições de níveis hierárquicos mais altos, possivelmente omitindo as informações mais periféricas (GRAN, 1998; ALEXIEVA, 1998).

\subsection{Explicação}

Pode ser que o intérprete se encontre numa situação em que nuances culturais, referências a instituições específicas ou outras expressões sem equivalência direta na língua de chegada sejam mencionadas. Nesse caso, o mais indicado é dar uma explicação rápida da primeira vez em que o termo é citado, 
caso haja tempo, e simplesmente citá-lo de maneira abreviada nas vezes subsequentes (JONES, 2002). Gile (1997) destaca, dentre as táticas para superar dificuldades momentâneas, a tática de explicar ou parafrasear determinados termos, lembrando que isso exigirá do intérprete a boa administração do tempo e da capacidade de processamento cognitivo.

\subsection{Entonação, Ênfase e Pausas}

Na comunicação oral, o sentido de uma mensagem é comunicado não só por palavras, mas também pela entonação, ênfase e pausas. Apesar do intérprete se sentir, muitas vezes, isolado do ambiente da palestra - no caso da cabine, na interpretação simultânea - ou temendo fazer breves pausas por receio do que pensarão os participantes do evento, a utilização adequada desses recursos da voz é essencial à compreensão da palestra (JONES, 2002). Obviamente, o intérprete deve ter cuidado para não enfatizar demais as palavras ou fazer pausas no meio das frases. Ele deve, ao contrário, sempre terminar suas frases com um tom descendente ao final, evitando ao máximo elevar a voz na última sílaba das palavras, o que pode dar a sensação de pergunta ou surpresa para o ouvinte. As pausas devem ser breves quando há a necessidade de marcação do discurso, entre um assunto e outro, e sempre após já ter concluído a frase (JONES, 2002). Sergio Viaggio $(1992)^{37}$ ressalta que a entonação pode, em alguns casos, até vir a substituir algum advérbio ou adjetivo que precise ser omitido, confirmando o fato de que a entonação pode ser utilizada como marcadora do discurso, também transmitindo coesão (VIAGGIO, 1992 apud GRAN, 1998).

\subsection{Números}

É importante desenvolver táticas para lidar com os números, principalmente na modalidade simultânea, em que há pouco tempo para a anotação. Números têm apenas um significado, ou seja, não há espaço para sua interpretação, e geralmente têm importância crucial. Os números são mais complexos do que parecem, pois envolvem valor aritmético, ordem de grandeza, moeda e seu valor relativo, ou seja, a que se referem (JONES, 2002). Roderick Jones (2002) sugere pronunciar o

\footnotetext{
${ }^{37}$ VIAGGIO, Sergio. Cognitive clozing to teach them to think. The Interpreter's Newsletter, v. 4, p. 40-44, 1992.
} 
número assim que é ouvido, reorganizando a frase a fim de acomodá-lo dentro do contexto. Uma outra tática é anotá-lo rapidamente assim que é ouvido, ou pedir para o colega anotar todos os números, liberando, assim, energia mental para lidar com o contexto em que os números surgem. É necessário estar atento à precisão, evitando ao máximo aproximações. Daniel Gile (1997) adverte que a anotação dos números acrescenta ao esforço de memória o esforço e tempo da própria anotação, lembrando que o intérprete deve se utilizar desta tática com cautela, sempre medindo seu custo-benefício em cada circunstância.

\subsection{Piadas, metáforas, ditados populares, citações e marcadores de discurso}

O intérprete deve evitar se comprometer com frases em que o orador anuncia que vai contar uma piada, utilizar uma metáfora, citar um autor conhecido, um ditado popular, ou listar "três pontos" marcadores de seu discurso, pois não sabe como a frase terminará, como irá verter o sentido para a língua de chegada, ou até mesmo se o orador listará os "três pontos" que prometeu. Ao invés de anunciar o que está por vir para os ouvintes, o intérprete deve simplesmente guardar aquela informação para si, para depois incluí-la ao final da frase ou quando for possível, dependendo do desenrolar do discurso (JONES, 2002). Esse tipo de estratégia permite ao intérprete estar aberto a um maior número de possibilidades de solução, evitando uma única direção. Assim, mudanças podem facilmente ser acrescentadas conforme necessário (RICCARDI, 1998). A estratégia de se comprometer o mínimo possível no início de frases possivelmente problemáticas é um bom exemplo de pensamento divergente, pois o intérprete imagina uma série de possíveis soluções enquanto o discurso ainda está sendo pronunciado pelo orador (HORVÁTH, 2010).

No caso de piadas, metáforas, trocadilhos e ditados populares, o intérprete deve sempre tentar traduzir da melhor maneira possível ou encontrar algo equivalente na língua de chegada, caso haja. Quando não for possível, o intérprete deve informar ao ouvinte que o orador está usando um trocadilho na língua de partida ou contando uma piada, e tentar explicar o sentido da mensagem da melhor forma. No caso das citações, o mais indicado é fazer uso de paráfrases ao invés de anunciar uma citação direta, explicando somente ao final de quem é a citação parafraseada (JONES, 2002). Roderick Jones (2002) ainda ressalta que é 
de suma importância que o intérprete não invente metáforas suas para traduzir o que o orador quis dizer. Isso pode complicá-lo mais à frente, caso um participante decida fazer uma pergunta com base na metáfora utilizada pelo intérprete que, na realidade, não foi usada pelo orador, ou ainda no caso de um evento com diversas línguas, em que alguns intérpretes decidam inventar metáforas e outros não.

\subsection{O uso criativo das estratégias}

O intérprete faz uso da criatividade quando demonstra flexibilidade na combinação e adequação de estratégias. É a combinação inesperada ou nova de técnicas conhecidas e seu uso apropriado que determina as características criativas de seu uso. Quando se dominam as regras, é possível violá-las sempre que necessário e apropriado, o que é outro modo de demonstrar criatividade (RICCARDI, 1998). O intérprete pode misturar a técnica do salame com a reformulação, pode ora explicar, ora economizar palavras, pode anotar os números para encaixá-los no melhor momento na frase, ao mesmo tempo em que cuida da entonação e da ênfase. Pode ainda se lembrar de um provérbio popular que em nada lembra o original em termos da estrutura linguística ou palavras utilizadas na língua de partida, mas que expressa o mesmo sentido e efeito na língua de chegada, sendo assim um tipo de reformulação. Riccardi (1998) ainda ressalta que as diferentes estratégias lidam tanto com as informações linguísticas quanto com as extralinguísticas, que estão em constante interação. São justamente as novas combinações das estratégias linguísticas e extralinguísticas que resultarão em diferentes níveis de criatividade (RICCARDI, 1998).

A personalidade criativa é aquela que tem mente ágil e flexível, que enxerga relações e correlações incomuns e as explora ativamente (HORVÁTH, 2010). A criatividade na interpretação é a capacidade de combinar, de novas maneiras, elementos previamente conhecidos, como as estratégias e técnicas. Essa reorganização não normativa que faz parte da interpretação é resultado, muitas vezes, da violação de estratégias e regras normalmente utilizadas na comunicação, o que é uma atitude criativa (RICCARDI, 1998).

Todas as estratégias mencionadas, dentre outras, se aplicam também à interpretação consecutiva. Porém, há algumas especificidades dessa modalidade 
que exigem o uso criativo de outros tipos de estratégia, conforme destacado a seguir.

\subsection{Estratégias para a interpretação consecutiva}

$\mathrm{Na}$ interpretação consecutiva, tendo em vista que o discurso interpretado ocorre logo após o discurso original, é necessário que o intérprete tenha uma escuta ativa e memória aguçada a fim de verter o sentido de tudo o que foi dito pelo orador - quer ele tenha pronunciado poucas frases ou gasto alguns minutos em sua elocução. A fim de auxiliar a memória e evitar sua sobrecarga, o intérprete faz bem ao se valer de anotações (JONES, 2002). As anotações, entretanto, não podem substituir a escuta ativa e a compreensão do discurso, que são fundamentais na interpretação (SELESKOVITCH, 1978). O intérprete deve escutar atentamente o discurso e compreendê-lo, ao mesmo tempo em que analisa o tipo de discurso que está sendo proferido, as ideias principais nele contidas e a ligação entre elas, tomando notas em forma de abreviações e símbolos a fim de "ativar" sua memória no momento de reexpressar a mensagem (JONES, 2002).

Há diversas dicas práticas de anotação: anotar sempre em disposição diagonal, fazer uma margem à esquerda para o registro dos elementos de ligação entre as ideias, itens listados devem estar sempre na vertical, dentre outros (JONES, 2002). É de suma importância, todavia, que o intérprete se lembre que a anotação deve facilitar a desverbalização e ajudá-lo a evitar a literalidade (SELESKOVITCH, 1975). Jones (2002) propõe ainda que o intérprete deve equilibrar o uso de símbolos e abreviações, de modo que sejam ferramentas pessoais úteis e de fácil acesso.

Há uma série de decisões a serem tomadas na interpretação consecutiva: o que selecionar para a tomada de notas, a escolha dos símbolos ou das abreviações, quais técnicas de anotação são mais bem-vindas em diferentes momentos do discurso e em diferentes discursos, além de também selecionar as palavras e expressões para verter o sentido na língua de chegada. Todas essas são escolhas que não são pré-determinadas, o que constitui, por definição, segundo Ludskanov (1971), um processo criativo, já que se trata de um processo não pré-determinado por regras (LUDSKANOV, 1971 apud ALEXIEVA, 1998). 
A interpretação consecutiva também envolve a ligação de ideias e a solução de problemas de maneira original e útil. Trata-se de um processo adaptativo que envolve a busca de informações e depende da memória, características mencionadas por Schank $(1988)^{38}$ como relativas à criatividade (SHANK, 1988 apud HORVÁTH, 2010). A interpretação consecutiva demanda o comportamento adaptativo do intérprete, pois há a necessidade de se ajustar a diversas situações. A criatividade pode ser entendida como a capacidade de se adaptar e sobreviver a novas circunstâncias (HORVÁTH, 2010). O orador pode não seguir um padrão de tempo de fala (ora fala alguns minutos, ora fala poucas frases), pode haver imprevistos que expõem mais a personalidade do intérprete, como no caso de precisar projetar a voz se houver problemas técnicos com o microfone, ou no caso de lidar com oradores bastante expressivos, precisando também corresponder na intensidade. Na interpretação consecutiva ainda há que se levar em consideração a relação das partes com o todo - as "partes" do discurso contidas na "vez do orador" com o todo do discurso, ou seja, o intérprete deve gerenciar a relação parte/todo (WERTHEIMER, 1945 apud RICCARDI, 1998) ${ }^{39}$.

O intérprete é encorajado, em seu treinamento, a criar seus próprios símbolos e abreviações práticas para a pronta utilização, além daqueles aprendidos em sala. Essas técnicas próprias, criadas para lidar com dificuldades ou situações específicas, além de métodos para "ativar" sua memória e "atalhos" para informações, são considerados por MacRae (1989)40 como um novo produto criado (MACRAE, 1989 apud HORVÁTH, 2010). Com o auxílio dos símbolos e das abreviações para a desverbalização (SELESKOVITCH, 1978), o discurso interpretado na língua de chegada será menos influenciado pela estrutura linguística da língua de partida. Riccardi (1998) afirma que quanto menos literal é a tradução, mais criativo é o desempenho na interpretação.

Com o tempo, o intérprete deve, cada vez mais, experimentar a combinação e o uso inusitado de diferentes estratégias, de acordo com o evento e com as circunstâncias. Ele deve aprender a "colecionar" estratégias que funcionaram bem,

\footnotetext{
${ }^{38}$ SCHANK, R. C. Creativity as a mechanical process. In: STERNBERG, R. J. (ed.). The nature of creativity: Contemporary psychological perspectives. Cambridge: Cambridge University Press, 1988. p. 220-238.

${ }^{39}$ WERTHEIMER, Max. Productive Thinking. New York/London: Harper, 1945.

${ }^{40}$ MACRAE, S. M. Information-crunching and other aspects of interpretation: Technique or creative process? In: HAMMOND, D. L. (ed.). Coming of age: Proceedings of the 30th Annual Conference of the American Translators Association, October 11-15, 1989, Washington, DC. Medford, NJ: Learned Information, 1989. p. 149-153.
} 
tanto na modalidade simultânea quanto na modalidade consecutiva, tomando nota de boas soluções após o evento. Quanto mais fizer uso das estratégias, mais irá “automatizá-las", liberando, assim, mais energia mental disponível para o uso da criatividade e minimizando o esgotamento da capacidade de processamento cognitivo (RICCARDI, 1998). Os intérpretes experientes, portanto, têm maior possibilidade de utilizar a criatividade, conforme veremos.

\subsection{A possibilidade criativa do intérprete experiente}

Para Gran (1998), já que as estratégias precisam ser assimiladas, o intérprete poderá fazer ainda melhor uso da criatividade mais tarde na profissão, quando já houver solidificado a prática das principais ferramentas linguísticas e cognitivas. Com a experiência, a tendência é que ocorra a automatização de alguns processos mentais envolvidos na interpretação - como a compreensão e análise, desverbalização e reexpressão da mensagem. A redução dos esforços cognitivos libera maior espaço para a criatividade. Riccardi (1998) destaca que os intérpretes mais experientes conseguem absorver informações mais rapidamente e fazer menos uso da omissão, por exemplo, pois são capazes de um maior armazenamento na memória. Os profissionais também conseguem vislumbrar melhor a relação parte/todo, integrar melhor os elementos linguísticos e extralinguísticos, reestruturar melhor a frase na língua de chegada e demonstrar maior capacidade associativa, além de também recuperar-se mais rapidamente de dificuldades momentâneas.

Dada a riqueza de sua experiência, alguns intérpretes profissionais contribuíram com esse trabalho, fornecendo exemplos práticos de soluções criativas em interpretação. Quatro exemplos serão descritos, a fim de ajudar o leitor a entrar em contato com o "mundo real" da interpretação: dois envolvendo soluções linguísticas e outros dois, soluções relativas ao comportamento criativo do intérprete. 


\subsection{Exemplos criativos na interpretação de conferências}

O primeiro exemplo é de um evento de tradução simultânea com equipamento portátil, numa reunião de conselho diretor de uma empresa. Um dos participantes, combinando o que faria na negociação que teriam na reunião seguinte, em que seria necessário propor aos sócios uma solução difícil, disse: "faremos assim, eu mordo, e você assopra". A solução para o inglês foi: "I'll be the good cop, you'll be the bad cop". A intérprete achou essa solução criativa por não ter sido nem uma solução literal, que naturalmente não caberia nesse caso, nem uma solução apenas pela explicação do sentido, que seria o mais natural e o que normalmente se faz com expressões idiomáticas. A equivalência possível entre as duas expressões não é óbvia, de modo que foi a criatividade, necessária a qualquer intérprete em quase todas as situações de trabalho, que ajudou a solucionar, em tempo real, essa expressão difícil de ser traduzida.

O segundo exemplo é de uma situação de entrega de prêmio, em simultânea. Sabemos que neste tipo de contexto tudo pode acontecer, o discurso é sempre inesperado. A pessoa que estava entregando o prêmio saiu do texto e disse: "O 'fulano' comprovou que o ditado de que 'quem nasceu pra araruta nunca chega a polvilho' não é sempre verdade." A interpretação foi a seguinte: "he proved that those who are said to be born to be number two, do make it to number one". A intérprete afirmou que, mediante as definições de criatividade apresentadas neste trabalho, toda e qualquer situação de interpretação demandará soluções criativas. Essa solução não foi "literal", nem tão inusitada quanto o discurso em português. No entanto, foi uma forma criativa de resolver o problema daquele ditado popular.

O terceiro exemplo é de um evento de mineração de 5 dias, com interpretação simultânea. O público consistia numa equipe brasileira e outra chinesa, definindo detalhes de um projeto conjunto. O problema foi que após uma manhã de apresentações em português feitas pela gerência da empresa brasileira, interpretadas para o inglês, começam os debates e percebe-se que a equipe chinesa não entende e/ou não fala bem inglês! A solução proposta pelas empresas foi a de contratar um intérprete de chinês (ou mais intérpretes, porque seriam várias salas de debate), que só chegaria no dia seguinte. A solução imediata foi apresentada pela intérprete coordenadora. Ela sai da cabine e propõe que se prossiga com os debates, usando um flip chart para auxiliar na comunicação entre as equipes. O 
resultado foi que os debates avançaram e o cliente agradeceu à intérprete coordenadora pela iniciativa. A solução final foi a de que dois intérpretes chineses foram contratados para auxiliar na interpretação em duas salas onde havia mais dificuldade, e duas outras salas permaneceram apenas com a interpretação em inglês e o auxílio do flip chart. Caso não tivesse sido proposto o uso do flip chart para ajudar na comunicação entre as equipes, o evento teria que ser suspenso até a chegada dos intérpretes de chinês, o que implicaria em perdas consideráveis de tempo e dinheiro para o cliente, além do constrangimento.

O quarto exemplo, que também envolve a iniciativa do intérprete para a solução de problemas, foi dado por Raffaella Quental (2004), em uma palestra em comemoração ao dia do tradutor, posteriormente transcrita no site do Sindicato dos Tradutores (SINTRA):

O caso emblemático do salvador da pátria aconteceu na viagem do presidente Lula para a Namíbia. Para quem não lembra, em 2003, Lula visitou a Namíbia, na África, como sempre acompanhado de seu intérprete oficial, o colega Sergio Xavier Ferreira, que, aliás, em fato inédito na história da República, tem o cargo de assessor especial do presidente. Ao saudar o presidente da Namíbia na chegada à capital do país, num discurso improvisado, Lula afirmou: "estou mais surpreso ainda porque quem chega a Windhoek não parece estar num país africano, nenhuma cidade é tão limpa e bonita [...]". De acordo com o que foi noticiado na imprensa, o intérprete nessa hora gaguejou e interrompeu o presidente (atrapalhando seu discurso, a rigor) para dizer: "desculpe, presidente, não estou entendendo." Mas, ao invés de criticar a interrupção, a imprensa disse que o intérprete ajudou o presidente a corrigir o que poderia se tornar uma gafe diplomática, ou seja, salvou a pátria...

(QUENTAL, 2004, site do SINTRA)

Vimos, nos exemplos acima descritos, diferentes exemplos de intérpretes profissionais que fizeram uso da criatividade em situações de interpretação tanto para soluções linguísticas, quanto para soluções que demandaram um comportamento criativo, mas que não eram necessariamente de caráter linguístico. Nessas circunstâncias, podemos perceber mais claramente o papel da criatividade na interpretação. Entretanto, há diversas outras ocasiões em que ela está presente, ainda que não tão visível.

Conforme defendemos ao longo do trabalho, o próprio processo de interpretação, em si, já é um processo criativo, dada a sua natureza de esforços cognitivos concomitantes, as escolhas necessárias e a solução de problemas. O aprendizado de como lidar com as mais variadas situações dura uma vida inteira, e 
nunca termina. Sempre haverá o inesperado, o inusitado, o impensável, pois o ser humano - a quem interpretamos — é imprevisível!

\subsection{Lidando com o inesperado: uma jornada para toda a vida}

Em geral, os intérpretes que se mantêm na profissão amam o que fazem. Têm prazer em interpretar, por diferentes motivos: pelo desafio intelectual e constante de novos assuntos, por tornar a comunicação possível entre pessoas de diferentes culturas e línguas, por ser um processo altamente estimulante, dado o nível de energia despendido, entre outras razões. Imagino que, entre os motivos de satisfação na profissão, esteja também a oportunidade de contribuir com a reformulação de um discurso ou fala, que gera algo novo. Tanto Roderick Jones (2002) quanto Alessandra Riccardi (1998) concordam que, na interpretação, o intérprete não só "repete" o que foi dito, mas está engajado na reexpressão da mensagem de tal maneira que cria, a partir do discurso de partida, o discurso de chegada, estando assim envolvido em um trabalho realmente criativo.

Laura Gran (1998) fala da beleza de trabalhar com idiomas, comparando esse trabalho com tocar bem piano. Há que se aprender as notas, as escalas, as composições e, gradualmente, internalizar os movimentos, até poder interpretar e desfrutar da música. Nós também, como intérpretes, aprendemos novas palavras, frases, unidades de sentido, diferentes tipos e estilos de discursos, até "dominarmos" cada vez mais as técnicas e estratégias, podendo assim desfrutar mais do processo e economizar energia. Luigi Luccarelli (2012), intérprete profissional e editor chefe da webzine "Communicate!” da AIIC (Associação Internacional de Intérpretes de Conferência), compara a interpretação a tocar jazz, partindo do pressuposto de que a interpretação é um processo criativo. Ele relata, em seu breve artigo no website da AIIC, que pesquisadores da Johns Hopkins Medicine, como Charles Limb (2008), estudaram a atividade cerebral de músicos durante a improvisação, utilizando imagens por ressonância magnética funcional. Limb (2008) comprovou que a região do cérebro mais "ativa" durante a improvisação é a mesma localização da assim chamada memória de trabalho do intérprete. Luccarelli (2012) conta algumas de suas próprias experiências com o jazz e com a interpretação, falando de como a improvisação o fascina. Segundo ele, a improvisação é algo que usamos constantemente, tanto na fala - enquanto 
falamos, estamos improvisando com palavras — quanto na solução de problemas imediatos.

Taylor-Bouladon (2007) fala do prazer que há no desconhecido, na imprevisibilidade da interpretação. Somos atraídos pelo desafio de não saber o que acontecerá em seguida, pelo espírito de aventura. Sentimo-nos também frustrados quando o inesperado nos atrapalha - aquela pessoa próxima ao orador que tosse no exato momento em que uma palavra essencial é proferida, aquele orador que "ultrapassa o limite de velocidade" na fala, ou aquele documento que está sendo lido a passos largos e não chega à cabine. Mas todas essas situações são compensadas pela satisfação de saber que se fez um bom trabalho, o melhor trabalho possível dentro das circunstâncias.

Os oradores são imprevisíveis, as pessoas são imprevisíveis, a vida é imprevisível. Estejamos conscientes do fato de que a profissão de intérprete sempre reserva muitos imprevistos, muitas situações inesperadas. Que façamos bom uso da criatividade para lidar com todo e qualquer problema que se apresentar. Conforme entoou Elis Regina: "vivendo e aprendendo a jogar... vivendo e aprendendo a jogar... nem sempre ganhando, nem sempre perdendo, mas aprendendo a jogar". 


\section{Conclusão}

Neste trabalho, busquei abordar a perspectiva da interpretação como um processo criativo. Vimos, a partir das definições de interpretação, das teorias da interpretação e das diferentes definições de criatividade e da personalidade criativa, que a interpretação é uma atividade que não só faz uso constante da criatividade, mas que necessita dela. Observamos que a criatividade não exclui a cultura geral e a preparação do intérprete, pelo contrário, é somente a partir desses elementos que a criatividade pode ser bem utilizada, e utilizada por todos. Não são somente os artistas que têm criatividade nata: todos temos alguma medida de criatividade que podemos desenvolver e estimular. Por fim, relembrei algumas estratégias comumente utilizadas na interpretação simultânea e consecutiva, ressaltando o seu uso criativo. Salientei o porquê dos intérpretes experientes terem maior potencial criativo, compartilhando alguns de seus exemplos práticos como ilustração do que pretendi demonstrar ao longo do trabalho. Espero que a perspectiva da interpretação como ofício criativo possa gerar nos intérpretes experientes, intérpretes em formação e leigos um apreço maior por essa atividade.

Percebemos que a criatividade é um instrumento a nosso favor na interpretação e que precisamos conhecê-la melhor. Acredito que ainda há muito a ser explorado acerca da interface entre criatividade e interpretação, pois trata-se de um tema vasto e surpreendentemente relevante. Horváth (2010) afirmou que seria proveitoso investigar até que ponto a criatividade do intérprete poderia fornecer um prognóstico com relação à sua aptidão para a interpretação e ao seu sucesso profissional. Outras possibilidades de estudo seriam as convergências entre energia mental e criatividade, interpretação e gênio criativo, e personalidade criativa e a aptidão para a interpretação. $O$ papel da criatividade na interpretação merece, portanto, um estudo mais aprofundado. 


\section{Referências Bibliográficas}

ALEXIEVA, Bistra. Consecutive Interpreting as a Decision Process. In: BEYLARD-OZEROFF, A., KRALOVA, J. \& MOSER-MERCER, B. (eds). Translators' Strategies and Creativity: Selected Papers from the $9^{\text {th }}$ International Conference on Translation and Interpreting, Prague, September 1995. In honor of Jiří Levý and Anton Popovič. Amsterdam: John Benjamins, 1998, p. 181-188.

FERREIRA, Aurélio Buarque de Holanda. Novo Dicionário Aurélio da Língua Portuguesa conforme a nova ortografia. Curitiba: Positivo, 2009.

(coordenação e edição Marina Baird Ferreira e Margarida dos Anjos, $4^{\mathrm{a}}$ edição)

FREIRE, Evandro Lisboa. Teoria Interpretativa da Tradução e Teoria dos Modelos dos Esforços na Interpretação: Proposições Fundamentais e Interrelações. In: Cadernos de Tradução (UFSC) v. 2, n. 22, 2008, p. 151-174.

GILE, Daniel. Basic Concepts and Models for Interpreter and Translation Training. Amsterdã e Filadélfia: John Benjamins Publishing Company, 2009.

GILE, Daniel. Conference Interpreting as a Cognitive Management Problem (1997). In: PÖCHHACKER, Franz \& SHLESINGER, Miriam (eds). The Interpreting Studies Reader. London and New York: Routledge, 2002.

GRAN, Laura. In-training development of interpreting strategies and creativity. In: BEYLARD-OZEROFF, A., KRALOVA, J. \& MOSER-MERCER, B. (eds). Translators' Strategies and Creativity: Selected Papers from the $9^{\text {th }}$ International Conference on Translation and Interpreting, Prague, September 1995. In honor of Jiří Levý and Anton Popovič. Amsterdam: John Benjamins, 1998, p. 145-162.

HENDRY, G. F. Your Future in Translating and Interpreting. New York: Richards Rosen Press, 1969.

HERBERT, Jean. The Interpreter's Handbook: How to Become a Conference Interpreter. Geneva: Georg and Cie, 1952.

HORVÁTH, Ildikó. Creativity in interpreting. Interpreting, v.12, n.2, p. 146$159,2010$.

JONES, Roderick. Conference Interpreting Explained. Manchester, UK \& Northampton, MA: St. Jerome, 2002.

KNELLER, George F. Arte e Ciência da Criatividade. São Paulo: IBRASA, 1985. (8 edição)

LEDERER, Marianne. Simultaneous Interpretation - Units of Meaning and Other Features (1978). In: PÖCHHACKER, Franz \& SHLESINGER, Miriam (eds). The Interpreting Studies Reader. London and New York: Routledge, 2002. 
LIMB, Charles J. This is your brain on jazz: researchers use MRI to study spontaneity, creativity. Johns Hopkins Medicine Website, 2008. Disponível em: $<$ http://www.hopkinsmedicine.org/news/media/releases/this_is_your_brain_on_ja zz_researchers_use_mri_to_study_spontaneity_creativity>. Acesso em: 25/06/2014.

LUCARELLI, Luigi. The jazz of interpreting. AIIC Website, 2012. Disponível em:

$<$ http://aiic.net/page/6254/the-jazz-of-interpreting/lang/1>. Acesso em: 25/06/2014.

NOVAES, Maria Helena. Psicologia da Criatividade. Petrópolis: Vozes, 1977.

PAGURA, Reynaldo José. A Teoria Interpretativa da Tradução (Théorie Du Sens) revisitada: um novo olhar sobre a desverbalização. TradTerm, São Paulo, v. 19, novembro/2012, p. 92-108.

PÖCHHACKER, Franz. Introducing Interpreting Studies. London and New York: Routledge, 2004.

QUENTAL, Raffaella de Filippis. O Intérprete: de "mal necessário" a "salvador da pátria". Site do SINTRA, 2004. Disponível em: $<$ http://www.sintra.org.br/site/index.php? $\mathrm{p}=\mathrm{c} \& \mathrm{id}=18 \& \operatorname{codcat}=13>$. Acesso em: $13 / 03 / 2014$.

RICCARDI, Alessandra. Interpreting strategies and creativity. In: BEYLARDOZEROFF, A., KRALOVA, J. \& MOSER-MERCER, B. (eds). Translators' Strategies and Creativity: Selected Papers from the $9^{\text {th }}$ International Conference on Translation and Interpreting, Prague, September 1995. In honor of Jiř́i Levý and Anton Popovič. Amsterdam: John Benjamins, 1998, p. 171-179.

ROZAN, Jean-François. La Prise de Notes en Interprétation Consécutive. Geneva: Georg and Cie, 1956.

SELESKOVITCH, Danica. Language and Cognition. In: GERVER, David and SINAIKO, H. Wallace (eds). Language Interpretation and Communication. New York: Plenum Press, 1978. p. 333-342.

Language and Memory: A Study of Note-Taking in Consecutive Interpreting (1975). In: PÖCHHACKER, Franz \& SHLESINGER, Miriam (eds). The Interpreting Studies Reader. London and New York: Routledge, 2002.

TAYLOR-BOULADON, Valerie. Conference Interpreting: Principles and Practice. $2^{\text {nd }}$ edition. Rotterdam: Museum Boijmans Van-Beuningen, 2007.

TORRANCE, E. P. \& TORRANCE, J. P. Pode-se ensinar criatividade? São Paulo: E.P.U., 1974. 